\title{
Research Design and Data Recovery Plan Archaeological Site 41WM13 at Norman's Crossing, Williamson County, Texas
}

Alan J. Wormser

Follow this and additional works at: https://scholarworks.sfasu.edu/ita

Part of the American Material Culture Commons, Archaeological Anthropology Commons, Environmental Studies Commons, Other American Studies Commons, Other Arts and Humanities Commons, Other History of Art, Architecture, and Archaeology Commons, and the United States History Commons

Tell us how this article helped you.

This Article is brought to you for free and open access by the Center for Regional Heritage Research at SFA ScholarWorks. It has been accepted for inclusion in Index of Texas Archaeology: Open Access Gray Literature from the Lone Star State by an authorized editor of SFA ScholarWorks. For more information, please contact cdsscholarworks@sfasu.edu. 


\section{Research Design and Data Recovery Plan Archaeological Site 41WM13 at Norman's Crossing, Williamson County, Texas}

\section{Licensing Statement}

This is a work produced for the Texas Department of Transportation (TxDOT) by the report producer. TxDOT and the report producer jointly own all rights, title, and interest in and to all intellectual property developed under TXDOT's contract with the report producer. The report may be cited and brief passages from this publication may be reproduced without permission provided that credit is given to both TXDOT and the report producer. Permission to reprint an entire chapter, section, figures or tables must be obtained in advance from either the Supervisor of the Archeological Studies Branch, Environmental Affairs Division, Texas Department of Transportation, 125 East 11th Street, Austin, Texas, 78701 or from the report producer. 
RESEARCH DESIGN AND DATA RECOVERY PLAN ARCHAEOLOGICAL SITE 41WM13

AT NORMAN'S CROSSING, WILLIAMSON COUNTY, TEXAS

Alan J. Wormser

State Department of Highways and Public Transportation

Highway Design Division

Austin, Texas

January, 1989 


\section{INTRODUCTION}

The Texas State Department of Highways and Public Transportation (SDHPT) will replace the bridge on CR 439 (signed "County Road 129") over Brushy Creek in the south-central part of the county at Norman's Crossing (Figures 1 and 2). The new bridge will be built just east of the present bridge. The present bridge will continue to be used until the new bridge is completed, which eliminates the need for a temporary detour easement. Additional right-of-way will be obtained east of the county road in order to construct the new bridge and approaches.

Site 41WM13 was located during routine inspection by Daymond Crawford of the SDHPT Cultural Resources staff. It is a prehistoric campsite on the south bank of Brushy Creek at Norman's Crossing, about 5 miles south of Hutto, Texas. Placement of the bridge approach on the south side of the creek will disturb the upper 50 to $100 \mathrm{~cm}$ of cultural deposit. Except for the location of piers, deposits deeper than $100 \mathrm{~cm}$ should not be disturbed, however no cultural deposits were detected more than $110 \mathrm{~cm}$ below the surface.

The site was originally reported in 1959 by E.M. Davis (Davis 1959), and has been known to local arrowhead collectors for a number of years. Alan Wormser of the SDHPT cultural resources staff conducted limited testing at $41 \mathrm{WM} 13$ in November and December 1988.

Most of the site will not be disturbed by the bridge project. Site limits were difficult to estimate since access to the site was restricted at the request of the landowners. However, the surface of the site west of the county road, and the creek banks on either side of the road were examined by members of the SDHPT cultural resources staff in order to determine site limits. To the west of the project the site is in a field which had recently been plowed. Ground visibility was excellent and a thin scatter of chert flakes, mussel shell, and burned rock was observed. The creek banks and road cuts show lenses of snail shell accumulations with occasional burned rocks typically 70 to $100 \mathrm{~cm}$ below the surface. In the road cuts, there is an additional 20 to $50 \mathrm{~cm}$ of light colored overburden which was determined to be construction waste from bridge and road maintenance over the last fifty years.

Although the site covers an area of about 4 acres, the bridge replacement will only disturb a portion of the site about 60 by 15 meters in size. This portion was once cultivated but is now a pasture with scattered elm, oak and pecan trees. Along the present east right-of-way fence, a strip of land about 5 meters wide is being used as a garden.

The study area is within the Blackland Prairie (Gould 1969), which occurs as a north-south belt in East Central Texas. Blair (1950) refers to this zone as the Texan Biotic Province and describes it as a transitional zone wirh characteristics of both the Austroriparian Biotic Province (eastern Texas pine and oak forests), and the Balconian Biotic Province (central Texas savannah). The Balconian Biotic Province corresponds with the Balcones Escarpment which marks the eastern boundary of the Edwards Plateau. The escarpment abruptly divides Williamson County, with roughly the eastern half of the county falling within the Blackland Prairie and the remaining western part of the county 
This Page Redacted Per THC Policy 
This Page Redacted Per THC Policy 
included within the Balcones Escarpment. A third environmental zone, the Post Oak Savannah (Gould 1969), occurs about 10 miles east of the site; immediately east of Williamson County. Thus, there are three distinctly different environmental zones within a relatively short distance east to west.

\section{DESCRIPTION OF THE SITE}

Site 41WM13 is on a terrace immediately adjacent to Brushy Creek. Brushy Creek is a dependable source of water and is given to violent and sudden flooding, which has been brought under partial control only in recent years. Archaeological sites are numerous along the creek and its tributaries.

The site follows the south bank of the creek west and upstream from the Brushy Creek bridge for a distance of about 200 meters. Although the site as a whole may be multicomponent, the portion to be affected lies at the eastern extremity of the site and appears to represent several occupations by a single cultural entity, or at least contains a strongly dominant Middle Archaic component.

Stratigraphy at the impacted area of the site is uncomplicated. The soil survey manual for Williamson County classifies the soil as Oakalla silty clay loam, which is a Cumulic Haplustoll (Werchan and Coker 1983). The A-horizon, as observed during testing, is a thick, dark gray clay loam extending from the surface to a depth of 80 or $90 \mathrm{~cm}$. This overlies an alluvial C-horizon made up of a light gray to yellowish silt loam. Weak paleosols and the crosssection of an ancient stream channel are visible in the creek bank upstream from the portion of the site which was tested. A trench was excavated during testing, but did not reveal any paleosols within the test area. Immediately adjacent to the road, the light colored alluvium composing the C-horizon also occurs as overburden above the A-horizon. The observed overburden is the result of construction waste accumulated during road construction and maintenance over the past 50 years. The overburden was not seen in any of the test units or the trench.

There seems to be only limited disturbance of the subsoil. Rodent burrows were infrequent, and tree roots mainly affected the upper $50 \mathrm{~cm}$ of soil. The major source of disturbance were cutter ant nests, some of which were over a meter deep.

Testing at 41WM13 revealed three features which were interpreted as hearths. They appeared as tight clusters of burned rock averaging about $50 \mathrm{~cm}$ in diameter and 8 to $10 \mathrm{~cm}$ thick at a depth of 60 to $70 \mathrm{~cm}$ below the surface. Below these, at a depth of 80 to $100 \mathrm{~cm}$, three diffuse clusters of burned rock were found. The uppermost clusters seemed to be undisturbed, while the lower, more diffuse clusters may have been disturbed prehistorically through the clearing of hearths, reuse of rocks or natural taphonomic processes. Mussel shell was found in most of the clusters, and charcoal was present only on the surfaces of a few of the rocks. Terrestrial snails (mainly Rabdotus sp.) occur throughout the soil matrix, but were especially frequent at the same depth as the hearth features. Flake counts followed the same pattern as the 
snail shell, and most of the stone tools were found 70 to $110 \mathrm{~cm}$ below the surface.

Three 2 by 1 meter units, and one 2 by 2 meter unit were excavated in $10 \mathrm{~cm}$ levels to depths of between 110 and $130 \mathrm{~cm}$ below the surface. In addition, a 2 by 8 meter trench was excavated by a Gradall to a depth of 3 meters.

Diagnostic artifacts recovered during testing include 4 Pedernales dart points, 1 Bulverde dart point, and a stemmed knife. These artifacts place the site within the Round Rock Phase of the Central Texas Middle Archaic Period, which dates between 4000 and 2600 B.P. (Weir 1976, Patterson 1977, Prewitt 1981).

Round Rock Phase sites typically are associated with so-called burned rock middens: large, massive, oval-shaped accumulations of burned rock. The actual purpose of burned rock middens has been a subject of debate among Texas archaeologists. Although at least partially created by dumping of burned rock as refuse, identifiable hearth configurations also occur within the middens. Most archaeologists now agree that these middens represent communal cooking or some form of plant food processing by seasonal aggregations of hunter/gatherer bands. Weir (1976) and Creel (1986) have further asserted that the burned rock middens were the result of acorn processing. Among other things, caches of white and red acorns are more resistant to infestation by insects if they have been roasted before being stored. Floral data are lacking to support this interpretation.

However, no burned rock midden was located within the area tested at 41 WM13. Although the area that was tested involved only a small portion of the site, it is possible that the site does not have a burned rock midden. Although a burned rock midden was reported at the Jaecks Hill site, 41WM472 (Denton 1985), burned rock middens are rarely found in the Blackland Prairie. This will be discussed in more detail shortly.

\section{SUMMARY OF ELIGIBILITY}

Site 41WM13 was determined eligible for the National Register of Historic Places on the basis of the information it contains concerning the Middle Archaic Period (criterion D, 36CFR Part 60.4). Broad research topics important to the study of this .period can be applied to this site, including cultural chronology, definition of the resource base, cultural adaptation, and diffusion of cultural traits.

Two significant characteristics of 41 WM13 are (1) the isolation of a single Round Rock phase component, and (2) the possible lack of a burned rock midden. In Central Texas, very few sites have provided an opportunity to study a discrete occupation for a single time period. Although Middle Archaic sites are abundant in Central Texas, few have undisturbed, isolated components. Middle Archaic sites west of the Balcones Escarpment are often associated with burned rock middens, while Middle Archaic sites east of the escarpment are almost never associated with burned rock middens. Since burned rock middens 
are activity-specific during the Middle Archaic, it is obvious that the human activities carried on east of the escarpment differ and it is likely that the portion of 41WM13 in question will provide new information for this particular time period.

RESEARCH DOMAIN

Archaeological Background

Site 41WM13 is probably a multicomponenet site. However, the portion of the site impacted by the bridge replacement project and which was tested by the SDHPT revealed only a single component from the Middle Archaic as perceived in Central Texas. Because the investigation will focus on a discrete occupation from a particular period, emphasis in this document will concentrate on that part of the prehistory of the region.

\section{Round Rock Phase}

The chronological sequences in the Central Texas Archaic are based primarily on projectile point typology and associated radiocarbon dates. Currently two versions of the chronology are in use: Weir (1976) has suggested a sequence which is more generalized and contains five time periods. On the other hand Prewitt (1981) refined Weir's time periods by splitting them into more categories. Johnson (1987) criticizes both schemes on methodological grounds, but does not offer an alternative. The definition of the Round Rock Phase represents the later half of the Middle Archaic Period in Weir's scheme and is the same as Prewitt's Round Rock and Marshall Ford Phases combined. The chronology presented below is based on that used for the North Fork and Granger Reservoir projects, and is a modified form of Weir's chronology.

The Round Rock Phase is the major period of the Central Texas Middle Archaic. Diagnostic artifacts for this time period include Pedernales and Bulverde dart points for the early portion of the phase, and Pedernales and Marshall dart points for the later portion of the phase. It is preceded by the Clear Fork Phase (Early/Middle Archaic) and superceded by the San Marcos Phase (Late Archaic). Round Rock Phase adaptations seem to derive out of the Clear Fork Phase and continue into later time periods.

The people of the Round Rock Phase are thought to have consisted of nomadic hunter/gatherer groups who exploited various resources seasonally. Burned rock middens occur in association with most Round Rock Phase sites and may represent periodic episodes where aggregations of hunting/gathering bands took part in communal food processing and cooking. Although burned rock middens in Central Texas have a variety of shapes (Weir 1976), Round Rock Phase is dominated by those with an oval shape.

The subsistence base seems to have stressed mussels, deer, and small game. Bison was not a large part of the subsistence, although bison remains are 
occasionally found. Floral resource exploitation is not well known, but acorns, pecans and walnut are plentiful.

Lithic resources are easily obtained. Along the Balcones Escarpment and on the Edwards Plateau there are many outcrops of chert, the local variety of which is called Georgetown chert. On the Blackland Prairie chert nodules are common in the creek gravels, where they have washed out of the Edwards Plateau. To the east and west of Williamson County many types of chert, jasper, and quartzite are available in Pleistocene gravel deposits called the Uvalde Gravels. Limestone is available throughout the area and the fossil oyster, Exogyra ponderosa, can be found in many of the Upper Cretaceous limestone deposits of the region.

Pottery making was unknown. As with many non-ceramic cultures in North America, cooking methods probably relied on the use of "boiling stones" and roasting. Some types of food were placed directly among the heated rocks. The apparent emphasis on mussels and the frequency of small burned rock clusters in association with mussel shell probably attests to this type of cooking method as well.

The material culture of the period was limited mainly to stone dart points and bifacial tools. Scraping tools are uncommon, and most are make-shift tools such as utilized flakes. Of the diagnostic implements, the Pedernales dart point is the most ubiquitous. It appears to have served as a multipurpose tool: used as a dart point, for cutting or drilling. These tools frequently show signs of wear, re-sharpening, and re-use.

There may be a distinction between the Round Rock Phase settlements on the Edwards Plateau and those of the Blackland Prairie and Post Oak Savannah. All the well-documented burned rock midden associations for the Round Rock Phase occur on the Balcones Escarpment and westward. Although burned rock middens may occur on the Blackland Prairie for other time periods, Round Rock Phase burned rock middens seem to be absent (Peter, Hays, and Demuynck 1982)

It is not known how many different ethnic or tribal groups are represented by Round Rock Phase sites, but Weir (1976) has suggested that there was a distinctive indigenous group in place in Central Texas by the Middle Archaic Period. The region to the southeast of the study area has been considered to be a transitional zone between Coastal, Eastern, and Central Texas cultures since it shares traits with each of those culture areas. However, Goode (1984) hypothesized that the "transitional zone" was also a separate, distinct cultural area in the Middle Archaic period, centered on Fayette and Bastrop Counties, Texas.

There is no evidence at present to indicate any major disruption of the Central Texas Archaic Tradition. However, the social organization of the people of these time periods, the length of time involved, and the extent of the Central Texas region is such that it is likely that the Round Rock Phase identifies a collection of hunter-gatherer groups with similar, generalized adaptations. It would be reasonable to assume that intraregional divisions occur, but the chronology of the sites from the Round Rock Phase is not refined enough to make such identification possible at this time. 


\section{$\underline{\text { Previous Research }}$}

The most completely documented archaeological sites in the county are in the North Fork Reservoir and Granger Reservoir; both on the San Gabriel River. Several sites in both reservoirs had components dating to the Round Rock Phase, but the only well-studied site in Central Texas with an isolated Round Rock component similar to that at 41WM13 is the Loeve-Fox Site, 41WM230, (Prewitt 1982) in Granger Reservoir, northeast Williamson County.

Other sites from the San Gabriel River with Round Rock Phase components include 41WM56, 41WM57, 41WM73, and 41WM304 from the North Fork Reservoir; and 41WM21, 41WM122, 41WM133, 41WM135, 41WM163, and 41WM267 in the Granger Reservoir (Moore 1977, 1978; Moore, Shafer, and Weed 1978; Hays 1982). Contrasts between these two reservoirs are interesting since the North Fork Reservoir is on the Balcones Escarpment while the Granger Reservoir is on the Blackland Prairie. On the Balcones Escarpment and Edwards Plateau, most of the Round Rock Phase sites are associated with burned rock middens. In the Blackland Prairie, Round Rock Phase sites tend to be deeply buried and appear not to be associated with burned rock middens.

The Wilson-Leonard site (41WM235) is several miles south of the North Fork Reservoir on Brushy Creek. It was a multicomponent site, but some portions of the site were well stratified. The Round Rock Phase at this site was expressed in the form of small hearth features, as at 41WM13 and at the LoeveFox site (41WM230).

To the southwest of 41WM13, the Bull Pen Site (41BP280) had an extensive Middle Archaic component (Ensor and Wille 1988). The Bull Pen Site may be of interest to the present study since it occurs in the Post Oak Savannah.

In addition, the Hoxie Bridge site, 41WM130 in Granger Reservoir, (Bond 1978) has features similar to those seen at 41WM13, but the components date from later time periods. Any research design for 41WM13 must address the concerns of the research conducted at these sites.

Literally hundreds of sites with Middle Archaic components are known for Central Texas. However, site 41WM13 is one of the few which has an isolated Round Rock Phase component. Because of the lack of isolated components, very little is known about the Round Rock Phase. Research into this time period has been largely limited to site-specific descriptions contained in brief cultural resources reports. Site 41WM13 offers an unusual opportunity for archaeologists to explore this time period at a single site and make comparisons with other sites of the region where the Round Rock component is not as clearly defined. 
Our understanding of the Round Rock Phase is limited, but many questions can be asked regarding the nature of human adaptation during this time period. Most of these questions can be addressed at 41WM13 and with reference to previous archaeological research in the region.

\section{Subsistence}

1. What is the range of faunal and floral resources used during the Middle Archaic Period?

2. In what ways are distributions of faunal and floral remains at Middle Archaic sites a reflection of strategic preferences, seasonality, or other cultural activities? In what ways are distributions of faunal and floral remains at Middle Archaic sites a reflection of resource availability?

3. What different activities include different types of food resources? How can processing of different types of resources be detected? How are the types of features found at Middle Archaic sites related to the utilization of specific resources?

4. How would a collection of specialized sites be used to exploit resources? Do different sites in the Middle Archaic appear to be staging areas for a small range of specialized activities?

5. Do any of the Middle Archaic sites appear to be base camps, or were the inhabitants engaged in a broader array of activities?

6. What is the significance of the different tool kits at different sites? Is the lack of specialized scraping tools indicative of all Middle Archaic sites, or just those at specific types of locations or where specific types of activities took place?

\section{Other Resources}

1. Where are the inhabitants of the Middle Archaic obtaining most of their lithic material? Is any of the material from outside the Central Texas region?

2. How far do sites occur from water, lithics, and overview areas? How do these relate to apparent site function?

3. Do the preferred resource procurement areas change through time? 
Regional Adaptations

1. Are there a differences between the Round Rock Phase sites of the Edwards Plateau and those of the Blackland Prairie and Post Oak Savannah? Do these reflect different ethnic groups, temporal differences, or seasonal adaptations - or some combination?

2. What are the purposes of the burned rock middens?

3. Do sites with burned rock middens represent aggregation, while other sites are disaggregations of people? If so, which of the sites without burned rock middens represent seasonal disaggregations and which represent specialized sites associated and co-occurring with burned rock midden sites? How does $41 \mathrm{WM} 13$ relate to models for population movement such as those proposed by Moore, Shafer, and Weed (1978)?

4. If the population increased during the Round Rock Phase as Weir has suggested (Weir 1976), what effects can be seen in settlement pattern or resource utilization?

\section{Technological Adaptations}

1. What sorts of tool kits are associated with sites of the Middle Archaic time period?

2. What are the methods used for resource procurement, food processing, tool manufacture, etc., which might identify sites of various function within the Round Rock Phase?

\section{Chronological Relationships}

1. Is there evidence of a cultural continuum from the Clear Fork Phase into the Round Rock Phase?

2. Is there evidence of a cultural continuum from the Round Rock Phase into the San Marcos Phase?

3. What is the spatial extent of the Round Rock Phase versus that of the preceding and succeeding phases?

4. Can the Round Rock Phase be more refined temporally?

5. Are there spatial differences within the Round Rock Phase? What markers could indicate distributions of slightly different groups of Round Rock Phase peoples throughout Central Texas?

6. Do the people of Fayette County to the east and southeast of Williamson County represent a distinct group compared with the people of the Balcones Escarpment/Blackland Prairie boundary. Are such distinctions true throughout the Round Rock Phase? Do the people to the east and southeast of Williamson 
County appear to be intrusive, transitional, or isolated relative to the rest of Central Texas in the Middle Archaic?

7. What evidence is there of interaction between Central Texas Middle Archaic people and contemporary people of surrounding regions? Does the direction of the interaction change through time?

Social Organization and Symbolism

1. What are typical group sizes that can be accounted for by the observed sites and site features?

2. What evidence is there of ceremonialism? Are there burials, caches, or other features?

3. Is there a preference for Exogyra shells at some sites or for certain types of features? Is this spatially or temporally significant?

4. Is there a patterned distribution of features within a site? Are there different activity-specific areas within Middle Archaic sites o fa given type? Are their arrangements patterned from site to site?

Research Goals

General Objectives

The proposed research at 41WM13 should address the concerns of previous archaeological work at North Fork Reservoir, Granger Reservoir, and the Wilson-Leonard site. A major focus of the study should be to explore the relationship between the Round Rock Phase sites of the Balcones Escarpment and Edwards Plateau versus those of the Blackland Prairie. The site functions, resource base, and seasonality of the various sites may help t oexplain many of the differences which have been observed.

Since the soils just east of the Balcones Escarpment are often thick alluvial deposits, Middle Archaic sites therefore tend to be deeply buried. Geomorphology should be considered in evaluating Round Rock Phase sites. The suggestion that archaeologists can identify distinct cultural groupings in Central Texas (Weir 1976) and the so-called transitional zone (Goode 1984) should also be explored. Chronological sequences for the Archaic Period are still evolving. If possible, the research at 41WM13 should contribute to our knowledge of adaptive variation during the Round Rock Phase.

Based on the above discussion and the questions listed in the previous section, the research at 41WM13 should concentrate on the following areas:

1. Intrasite patterning of features and artifacts

2. Settlement/subsistence patterning

3. Identification of the resource base 
4. Indigenous and nonresident cultural traits (if any)

5. Development of the local chronological sequence

6. Examination of the geomorphology of the region

\section{Subsistence}

Site 41WM13 may yield ethnobotanical and faunal remains which will assist researchers in identifying subsistence resources. The types and diversity of artifacts and features can be used to further interpret resource utilization. Flotation analysis is recommended for at least a portion of the fill of features, especially those likely to yield botanical remains.

Few Round Rock Phase sites have been the subject of in-depth study. Yet the nature of the subsistence base is essential to our understanding the function of site 41WM13 within a larger system of sites. When data on other sites from this time period become available, the information derived from 41WM13 will be incorporated into the body of knowledge at that point.

Different food resources require different types of processing. Obvious examples are butchering and preparing game, using corn, or preparing acorns for storage. In each case there would be identifiable tool kits and storage/processing facilities specific to the activity in question.

Nomadism requires strategies which take advantage of resources which are not available year-round. Site placement and site specialization would be expected in such a situation. Different sites should be identifiable by the range and types of activities as evidenced in the presence or absence of specific features and artifact types. Features would include storage pits, hearths, refuse piles and pits, and food processing areas within 41WM13.

\section{Other Resources}

As discussed earlier in this document, lithic resources are readily available among the stream cobbles and gravel deposits of the region. Even so, it may be possible to discern subtle differences in color, fossil inclusions, or the chemistry of the various lithic materials found at 41WM13. Rocks which would be curated and traded by prehistoric people might include cherts, obsidian, novaculite, or crystalline quartz. The sources of these materials might indicate migration routes, trade relationships, or other orientations in a particular direction. Such affiliations would be expected to change through time as political and environmental conditions changed or new adaptation strategies evolved,

Coupled with assessments of site function, site placement within the Brushy Creek drainage would be another indicator of resource utilization. Here the concept of a "resource" can be used loosely to include any traits that would give the site an advantage as a strategic location. Overview areas and locations which are protected due to their slope and direction of orientation, tree cover, etc., would fall within this category. 


\section{$\underline{\text { Regional Adaptations }}$}

In order to assess 41WM13 in terms of a regional perspective, the researchers must consider other sites with Round Rock Phase components within Williamson and the surrounding counties. The purpose of specific features such as burned rock middens cannot be addressed directly at 41WM13, but such questions can be discussed in a general way by references to other sites of the same time period.

\section{Technological Adaptations}

As mentioned before, the types of tools present at 41WM13 would aid in identifying site activities. Likewise, the diversity of tools present at the site would indicate the degree of specialization of those activities. The site could then be compared with other sites to determine differences in tool kits and the types of sites typical of the Round Rock Phase.

Additionally, use-wear analysis would identify tools which were multifunctional or abandoned at various stages of manufacture or use. Manufacturing techniques could be examined, considering what types of manufacturing and resharpening activities were taking place when the site was occupied. Any distinctive methods of tool manufacture should be noted. When data from other Round Rock Phase sites are available, comparison of lithic technology may show geographical variation and would aid in identifying different Round Rock Phase populations.

\section{Chronological Relationships}

Evidence of a cultural continuum from the Clear Fork Phase through the Round Rock Phase and the San Marcos Phase will be difficult to address at 41 WM13 if the site is considered in isolation. Even from a regional perspective, the assertion'that there is such a continuum is difficult to assess at this time since it is not known how many regional variants exist for each of the three phases, or how those variants relate to different groups of people and their movements. Sudden changes in technology, adaptive strategy, or other cultural practices would be evidence of some sort of dramatic population or adaptive shift. However, the absence of such shifts among scattered bands of hunter/gatherers over several millennia do not necessarily indicate continuity .

Spatial relationships may be easier to detect, if there are specific tool types and variants which exhibit distinct geographical patterning within a single time period. Such may be the case for the Round Rock Phase. As has been mentioned, the sites from this time period in nearby Fayette county share traits which suggest the presence of an identifiable prehistoric group; separate from other Middle Archaic people of Central Texas. The relationship of the 41WM13 to these and any other potential groupings should be explored. 
Social Organization and Symbolism

Although exact size of a population at a site is impossible to estimate, Prewitt suggested that Middle Archaic occupations at the Loeve-Fox site were comprised of small groups of several individual families. He made this assessment based on the size and distribution of small hearths and their associated artifacts. House structures are unknown for this time period. But the dichotomy between the loose scatter of hearths seen at some sites and the massive accumulations at sites with burned rock middens suggest that the group sizes at the two types of sites were substantially different.

The preferred use of Exogyra ponderosa shell in rock hearths has been noted at the Loeve-Fox site. Testing at 41WM13 suggested that a similar preference might be occurring. The reason for this preference, if it actually exists, is unknown at present. Research at 41WM13 should address this issue if the pattern appears to be present after further excavation has been done.

Features which might be of religious or symbolic importance should be examined carefully. Almost nothing is known about the ceremonialism of this time period. Features such as burials and caches may be present at 41WM13, although no evidence of such features were found during testing. At present, little is known about burial practices during the Round Rock Phase.

METHODS

The methods outlined below will enhance data recovery and optimize the potential to address the questions discussed in the previous sections of this document.

Excavation will be confined to the area south of Brushy Creek, on the east side of County Road 439 within the right-of-way. Because little cultural material was found in the upper $40 \mathrm{~cm}$ of the site during testing, mechanical excavation may be used to remove the upper 30 to $40 \mathrm{~cm}$ of topsoil. Beginning at a depth of no more than $40 \mathrm{~cm}$, the excavations should proceed by hand. Before mechanical excavation is used, a detailed topographic site map should be prepared showing elevations of various points at the surface of the site. The site map should show the site grid in relation to the present bridge and road, as well as to the old and new right-of-way lines. New excavation units should be tied into the test units which were excavated in December 1988 by the SDHPT cultural resources staff.

The recovery effort will take up to 6 weeks, with an additional 2 weeks allowed for unplanned contingencies (e.g., rain days, discovery of skeletal or other unusual or fragile features, etc.). The area will be excavated in 1 by 1 meter units, although they may be arranged to form 1 by 2 meter or 2 by 2 meter blocks, or larger. Levels will be no greater than $10 \mathrm{~cm}$ in depth. Control of the levels may be with transit, or line and line levels with a known, nearby reference point. 
A total of at least thirty (30) 1 by 1 meter excavation units should be excavated during data recovery in addition to the units which were excavated during the testing. During the testing phase of the project, the equivalent of ten (10) 1 by 1 meter units were excavated for a total of the equivalent of 108 standard levels (each 1 by 1 by 0.1 meter). Considering the range and densities of features and artifacts observed during testing, and the size of the area to be affected by the project, the number of excavation units recommended should be adequate to sample the site. Data obtained from any additional units would be limited by diminishing yields and repetition of site information.

During testing, it was found that features and artifacts were concentrated within 35 meters of the creek bank. The placement of the excavation units should focus on this portion of the affected area, but still sample the area beyond the 35 meter $1 \mathrm{imit}$. It is recommended that 20 of the 30 units be within 35 meters of the creek bank, and that the remainder be in the periphery further from the bank. Flexibility in these proportions should be left to the discretion of the researcher based on observations in the field.

The excavation units nearest the creek should be oriented to create one or more blocks of adjacent squares. Care should be taken to isolate occupation zones and features. Finer excavation should take place around features. In general, the excavation strategy should be oriented toward opening a wide area in order to examine relationships between features and activity areas around features.

The bottom of each excavation level should be scraped with a trowel and level forms should be filled out at the end of each level to indicate features, krotovina and other disturbances, and changes in soil texture or color. In addition, all artifacts found in situ should be plotted and their elevations recorded whenever possible.

Dry screening should be done with $1 / 4$-inch mesh. Water screening should be accomplished using 1/16-inch mesh.

At least three of the 1 by 1 meter units should be selected for flotation and soil samples. For each of these excavation units, a consistent volume of soil (e.g., 10 by 10 by $10 \mathrm{~cm}$ ) should be sampled for each level excavated in order to obtain a column of samples.

A sample of matrix of consistent volume will be removed from the fill of each feature for flotation analysis. The remainder of the fill will be waterscreened through $1 / 16$-inch mesh. This will assist in the recovery of macrobotanical remains, faunal remains, and smaller debitage. The flotation sample for each feature should be analyzed for pollen, organic material, and soil constituents as well as artifacts.

Features such as suspected pits, hearths, and burned rock clusters should be cross-sectioned to determine their shape. Sketches of these cross-sections should be made and notes about the cross-section should appear on the profile sketch or in the crew-chief's daily field journal. This may be important since other Round Rock Phase sites frequently have small basin-shaped burned 
rock features (as opposed to flat or piled rocks). Also, the relative depths and shapes of pits may indicate functional or temporal differences.

When excavation has reached its terminal depth, profile drawings should be made of all excavation units, or blocks of units.

Faunal remains, botanical remains, soil samples, flotation, and other specialized samples should be examined during the analysis phase of data recovery.

\section{ANALYSIS}

Site materials will be processed and prepared for analysis. Special samples will be packaged and sent to appropriate laboratories. Artifact inventories should be prepared and should appear in the final research report.

An effort should be made to identify stone, bone, and other tools recovered during the excavation of the site, with emphasis on tool use/manufacturing and site function. In order to address resource availability and exploitation, the type of lithic materials used for tools, and the probable sources of each material type, should be identified.

Non-local and other atypical elements at the site should be identified. Such items might include marine shell, copper, obsidian and other "exotic" lithics, or features not usually associated with the Central Texas Archaic. The possibility of trade and curation of such artifacts should be considered, as well as the possibility of intrusive occupations at the site (should the evidence warrant it).

Faunal remains will be identified as to species, when possible. The faunal remains should be interpreted in terms of their utilization and availability at the site. Seasonal availability should also be examined.

The spatial organization of the site, with associated artifacts, may provide additional information about activities within the site, the size and nature of the human groups occupying the site, and the relationship of 41WM13 to other sites with Round Rock Phase components. A typology should be developed for the features identified at 41WM13, and comparisons should be made with other sites from the same time period.

The SDHPT cultural resources staff will make material recovered during the testing phase at 41WM13 available to the researchers as needed. The results of the testing phase of the mitigation should be incorporated into the draft and final report of research at the site. The site data should be viewed in the light of regional concerns.

A report of the data recovery and analysis in draft and final form will be submitted to the Texas State Department of Highways and Public Transportation, which will in turn submit the documents to the Office of the State Historic Preservation Officer for comment. 
CONSULTANTS AND SPECIAL STUDIES

Geomorphology

Soils Analysis

Ethnobotanical/ Flotation

Faunal Analysis

Radiocarbon dating

Lithic Analysis
Dr. Michael Waters, Department of Anthropology, Texas A \& M University

Department of Soil and Crop Science, Texas A \& M University

Archeological Research Laboratory, Texas A \& M University

Dr. Gentry Steele, Department of Anthropology, Texas A \& M University

Alpha/BetaAnalytic, Coral Gables, Florida

Archeological Research Laboratory, Texas A \& M University 
REFERENCES CITED

Blair, Frank W.

1950 The Biotic Provinces of Texas. Texas Journal of Science 2(1).

Bond, Clell L.

1978 Three Archeological Sites at Hoxie Bridge, Williamson County, Texas. Report No. 43. Anthropology Laboratory, Texas A \& M University, College Station.

Bryant, Vaughn M., Jr.

1978 Analysis of Soils and Fossil Pollen from 41WM21. In Appendix A, Archeological Test Excavations at 41WM21, Williamson County, Texas (by G.L. Moore). Report Number 37 (Revised by H.J. Shafer, E.P. Baxter, J. Ippolito, and C.L. Bond). Research Foundation, Texas A\&M University, College Station.

Creel, Darrell G.

1986 A Study of Burned Rock Middens in West Central Texas. Ph.D. dissertation, University of Texas, Austin.

Davis, E. Mott

1959 Site form on file at the Texas Archaeological Research Laboratory, University of Texas at Austin.

Denton, Joe T.

1985 Archaeological Testing of Site 41WM472, the Jaecks Hill Site, Williamson County, Texas. Texas State Department of Highways and Public Transportation, Austin.

Ensor, H. Blaine, and Catherine S. Mueller-Wille

1988 Excavations at the Bull Pen Site 41BP280, Colorado River Drainage, Bastrop County, Texas. Contract Reports in Archaeology,Report

No. 3, Texas State Department of Highways and Public Transportation, Austin.

Goode, Glenn T.

1984 Archaeological Testing and Recommendations for the Kennedy Bluffs Site, 41BP19, in Bastrop County, Texas. Texas State Department of Highways and Public Transportation, Austin.

Gould, F.W.

1969 Texas Plants: A Checklist and Ecological Summary. Texas Agricultural Experiment Station, Texas A \& M University, College Station.

Hays, T.R. (editor)

1982 Archaeological Investigations at the San Gabriel Reservoir Districts, Central Texas, Volumes I, II, and III. Institute of Applied Sciences, North Texas State University, Denton. 
Johnson, LeRoy

1987 A Plague of Phases: Recent Sociocultural Taxonomy in Texas

Archeology. Texas Archeological Society, Bulletin 57:1-26.

Moore. Gary L.

1977 An Archaeological Assessment of Sites 41WM21, 41WM24, and 41WM133 in Granger Reservoir, Williamson County, Texas. Report submitted to the National Park Service by the Anthropology Laboratory, Texas A \& M University, College Station.

1978 Archeological Test Excavations at Site 41WM21, Williamson County, Texas. Report Number 3 (Revised by H.J. Shafer, E.P. Baxter, J. Ippolito, and C.L. Bond). Research Foundation, Texas A \& M University, College Station.

Moore, Gary L., Harry J. Shafer, and C.S. Weed

1978 Archeological Surveys of the Granger and North Fork Reservoirs: Volume I, The Granger Report. Anthropology Laboratory, Texas A \& M University, College Station.

Patterson, Patience E.

1977 A Lithic Reduction Sequence: A Test Case in the North Fork Reservoir Area, Williamson County, Texas. Unpublished M.A. thesis, University of Texas at Austin.

Peter, Duane E., T.R. Hays, and Marie-Anne Demuynck

1982 Synthesis: The Archaeology of the San Gabriel Reservoir Districts. In Archaeologica Investigations at the San Gabriel Reservoir Districts, Central Texas, Volume 2, T.R. Hays, editor. North Texas State University, Denton.

Prewitt, Elton R.

1981 Cultural Chronology in Central Texas. Texas Archaeological Society, Bulletin 52: 65-90.

1982 Archaeological Investigations at the San Gabriel Reservoir Districts, Central Texas, Volume 4. Institute of Applied Sciences, North Texas State University, Denton.

Weir, Frank A.

1976 The Central Texas Archaic. Ph.D. dissertation, Washington State University, Pullman, Washington.

Werchan, Leroy E., and John L. Coker

1983 Soil Survey of Williamson County, Texas. United States Department of Agriculture, Soil Conservation Service, Washington, D.C. 
HUMAN SKELETAL REMAINS

ADDENDUM TO THE RESEARCH DESIGN

Introduction

During excavation of Site 41WM13, human skeletal remains were encountered. The presence of a burial had not been anticipated in the research design for the site. This addendum will address the burial: its identification, notification of Native Americans, research questions, field methods, and disposition of the remains.

Identification

A burial pit was found beginning at about $100 \mathrm{~cm}$ below the surface and extending to $150 \mathrm{~cm}$ or more in depth. The burial is near the excavation grid point N126E97. The current excavation grid is the same as that used during the testing phase of this project. The human remains consist of a femur, radius, ulna or fibula, a second femur or tibia, and a humerus and cranium at 130-150 cm depth. Only a portion of the burial is exposed at this time; however, the bones appear jumbled, with long bones oriented in several different directions. They are apparently disarticulated. Two interpretations are considered likely: (1) the burial is a secondary, bundle burial, and/or (2) the burial includes more than one individual.

A pit outline is visible from a depth of $110 \mathrm{~cm}$ and below. The pit may be circular and about $50 \mathrm{~cm}$ in diameter, or it may extend eastward into a unit which has not yet been excavated. The sides of the pit are straight.

Above the human remains, from a depth of 110 to $130 \mathrm{~cm}$ below the surface, the burial pit is filled with deer antler, bone, and large limestone rocks, some of which have been burned. Rocks are oriented horizontally, vertically, and diagonally. Small waste flakes of chert also occur in the pit fill, but no cache or large flakes have been found. Outside of the burial feature there are almost no flakes or other artifacts below $120 \mathrm{~cm}$ depth. The burial pit therefore appears to have been originally dug into the sterile soil underlying the Round Rock Phase component. 
Around the burial feature to the north, south, and west, several other features have been found. They do not appear to be related to the burial, however. About $50 \mathrm{~cm}$ to the west is a small cluster of burned bone designated Feature 19. The bone cluster extends from 115 to $125 \mathrm{~cm}$ below the surface and is about $10 \mathrm{~cm}$ in diameter horizontally. None of the bone looks human, but it is too fragmentary for an accurate field identification.

About $120 \mathrm{~cm}$ to the south was another cluster of burned bone (Feature 21). A broken Pedernales dart point was found among the burned bone. The feature is about $40 \mathrm{~cm}$ long by $20 \mathrm{~cm}$ wide and is oval in outline. A dark pit outline was visible around the bone cluster. The feature was examined in cross section and the bottom of a small basin-shaped pit was visible. The feature extends from a depth of 128 to $145 \mathrm{~cm}$ below the surface and is interpreted as a trash pit. The bone is burned and highly fragmented, and conclusive identification has not been possible in the field.

\section{INTERPRETATION}

Antler in association with Late Archaic burials has been found at Loma Sandia (41LK28) and 41BX1. These sites are about 150 and 100 miles south of site 41WM13, respectively. Closer to the site, antler in grave pits was found at the Loeve-Fox site (41WM230) in Granger Reservoir, about 10 miles to the north. These burials were associated with a ring of cremations and are interpreted as a formal cemetery. The graves at Loeve-Fox dated to the Austin Phase of the Late Prehistoric Period.

Because of the proximity of concentrations of burned bone to the burial at 41WM13, Dan Prikyl of the Texas Historical Commission (THC) has suggested that the burial may represent part of a cemetery and that consideration should be given to the possibility that the concentrations of burned bone (Feature 19 and Feature 21) may represent cremations. It has not been established whether these features contain human or nonhuman osteological remains. The archaeological staff of the Texas State Department of Highways and Public Transportation (SDHPT) consider it premature to assume that a cemetery has been encountered. All bone recovered from these features will be examined by a human osteologist as well as by a faunal analyst in order to determine whether additional human bone is present or whether these contentrations contain only nonhuman animal bone. The evidence thus far indicates that there is a single burial pit and two concentrations of burned 
bone 50 and $120 \mathrm{~cm}$ away from the edge of the burial pit. There is no evidence to indicate that the burned bone in Features 19 and 21 is human. In the case of one of the features (Feature 21), there is a suggestion that the bone may be deer. During the testing phase, the equivalent of six $1 \times 1$ meter units was excavated to a depth of $130 \mathrm{~cm}$ below the surface in the vicinity of the burial. Little bone was recovered and no burials or pit stains were found.

While other burials may be present at the site, there is, at this time, no evidence for more than one burial episode, probably with more than one individual interred in the burial pit. There is no evidence of a cemetary area. The burial appears to be affiliated with the Middle Archaic component at the site.

$\underline{\text { Notification of Native Americans }}$

Immediately upon discovery of the burial, Frank Weir of the SDHPT archaeological staff notified State Archeologist Robert Mallouf as well as the Texas Historical Commission. Robert Mallouf followed standard procedures and notified Ray Apodaca, Director of the Texas Indian Commission, the agency which handles Native American concerns in Texas. No special problems are anticipated regarding issues of interest to Native Americans. The SDHPT will continue to coordinate with appropriate Native American representatives through the office of the State Archeologist.

Research Questions

Because of the discovery of the burial, new research questions can be addressed for Site 41WM13. The questions discussed in the original research design remain unchanged, but now questions regarding the burial can be integrated into the original design.

Interpretations based on a single burial at a site are necessarily limited. Because the burial practices evidenced at 41WM13 are similar to other burials in the region, comparisons to contemporaneous sites with burials can be used. of primary importance, then, is:

(1) what time period/site component is the burial affiliated with?

(2) what other sites have similar burials?

(3) is there evidence of a religious/ethnic continuity through the Middle and Late Archaic periods? 
These questions relate directly to the questions proposed in the original research design. The original research design stresses spatial relationships between Middle Archaic sites and cultural continuity throughout the Archaic periods.

In order to answer these questions;

(1) bone and antler will be collected from the burial fill for carbon-14 dates;

(2) charcoal, if present, will be collected from the burial fill for carbon-14 dates;

(3) excavation of the burial will be conducted so that spacial context and associations are readily apparent: Numerous plots and photographs will be made and notes taken;

(4) the burial pit fill will be collected in soil bags, and flotation and water-screening techniques will be used to recover material that could be lost using dry-screen techiniques; and

(5) data on other prehistoric burials in Central Texas will be compiled for comparative purposes.

Final Disposition

The burial and associated artifacts will be retained by the SDHPT until the analyses have been completed. The material will then be transferred to the Texas Archeological Research Center at the Balcones Research Center, University of Texas at Austin, Texas. In accordance with procedures established in the State of Texas, we will coordinate with the Office of the State Archeologist, the Office of the State Historic Preservation Officer, appropriate Native American representatives, and the Texas Antiquities committee. 
RESULTS OF ARCHAEOLOGICAL TESTING AT SITE 4IW M 13 WILLAMSON COUNTY, TEXAS

\author{
Alan J. Wormser
}

Texas

State Department of Highways and Public Transportation

Highway Design Division

January 1989 
Archaeological site 41WM13 was tested by the cultural resources staff of the State Department of Highways and Public Transportation (SDHPT) in November and December 1988. A 60 by 15 meter portion of the site will be affected by a bridge replacement project on County Road 439 (signed "CR 129"). Cultural deposits were found to extend from the surface to a depth of abou $90 \mathrm{~cm}$. The upper $40 \mathrm{~cm}$ of deposit contained relatively little cultural material. Evidence of prehistoric occupation such as lithic debris, burned rock, mussel shell, and stone implements, increased with depth. Burned rock features were found at 70 to $90 \mathrm{~cm}$ below the surface, and most of the artifacts recovered also came from this zone. Site 41WM13 appears to have been occupied during the Round Rock Phase of the Middle Archaic period. Although other components may be present at the site, it appears that the Round Rock Phase component is isolated or strongly dominant in the portion of the site to be affected by the bridge replacement.

The site meets the criteria for eligibility for the National Register of Historic Places (CRF 36, Part 800) since there is a dominant and apparently isolated Middle Archaic component, intact deposits and undisturbed features, and a high potential that additional research at 41WM13 would further our understanding of the Round Rock Phase in Central Texas. 
TABLE OF CONTENTS

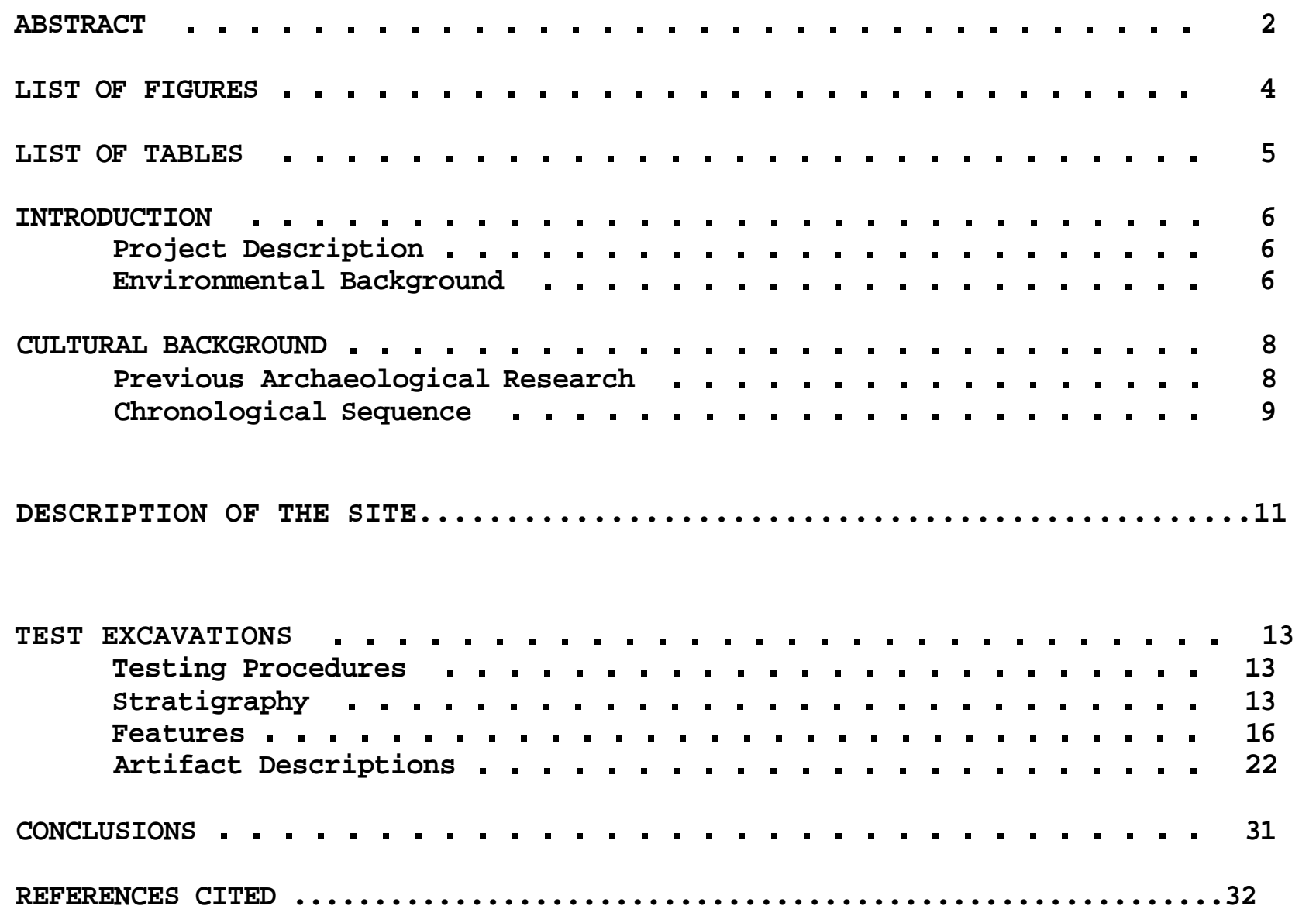




\section{LIST OF FIGURES}

FIGURE 1. Location of $\mathrm{S}$ ite 4lWM13............ FIGURE 2. Location of the Test Units and Gradall Trench at FIGURE 3. Profile of Road Cut. East Side of CR 439... . FIGURE 4. Profile of the West Wall of Test Unit N122/E99. FIGURE 5. Test Unit N108/E99. Level 9. Features 1 and 2. . FIGURE 6. Test Unit N122/E99, Level 7. Feature 3. . . . FIGURE 7. Test Unit N132/E99, Level 7. Features 4 and 5. . FIGURE 8. Test Unit N132/E99, Level 8. Feature 4. 5. and 6 FIGURE 9. Knife and Dart Points from 4lWM13. . . . . . . FIGURE 10. Bifaces from 4lWM13. . . . . . . . . . . FIGURE 11. Assorted Artifacts from 4lWM13. . . . . . 


\section{LIST OF TABLES}

TABLE 1. Artifacts recovered from Features 1 through 6. . . . . . . . 21

TABLE 2. Faunal remains recovered from Features 1 through $6 . . . . .21$

TABLE3. Artifact summary. . . . . . . . . . . . . . . . . . . . . . . . 26

TABLE4. Faunalremains. . . . . . . . . . . . . . . . . . . . . 28 


\section{INTRODUCTION}

\section{Project Description}

The Texas State Department of Highways and Public Transportation (SDHPT) will construct a new bridge on County Road 439 at Brushy Creek in Williamson County about $1 / 2$ mile south of the community of Norman's Crossing and five miles southeast of the town of Hutto, Texas. The project will replace an existing bridge built in 1930, but which is not considered eligible for the National Register.

Site 41WM13 was first discovered by DR. E.M Davis in 1959. It was noted again during a routine survey of the project by the SDHPT cultural resources staff in the Spring of 1988. Archaeological testing was conducted in November and December 1988. A total of four test units were excavated. Three of these were 1 by 2 meters in size, and one was 2 by 2 meters. The units were excavated to depths of 100,120 and $130 \mathrm{~cm}$. Six features were identified at 70 to $90 \mathrm{~cm}$ depth. A 11 were small clusters of burned rock typically about $50 \mathrm{~cm}$ in diameter. In addition, one trench was excavated using a Gradall. The trench was about 10 meters long, 2 meters wide, and 2.3 meters deep.

There appears to be an isolated or strongly dominant Round Rock Phase component at the portion of the site to be affected by the bridge construction and the deposits exhibit little disturbance. The site is considered eligible for inclusion on the National Register and the cultural resources staff of the SDHPT has prepared a Data Recovery Plan for submission to the Office of the State Historic Preservation Officer (SHPO).

\section{Environmental Background}

The study area is within the Blackland Prairie (Gould 1969). This environmental zone occurs as a north-south belt in east central Texas. Blair (1950) refers to this zone as the Texan Biotic Province and describes it as a transitional zone with characteristics of both the Austroriparian Biotic Province (eastern Texas pine and oak forests), and the Balconian Biotic Province (Central Texas savannah). The Balconian Biotic Province corresponds with the Balcones Escarpment which marks the eastern boundary of the Edwards Plateau. The escarpment abruptly divides Williamson County, with roughly the eastern half of the county falling within the Blackland Prairie and the remaining western part of the county included within the Balcones Escarpment. About $10 \mathrm{miles}$ to the east of 41WM13, the Post Oak Savannah occurs (Gould 1969). Thus, there are three distinctly different environmental zones within a relatively short distance east to west. 
This Page Redacted Per THC Policy 


\section{Previous Archaeological Research}

Campbell (1948) reported on excavations at the Merrell Site, which was excavated during the 1930's and early 1940's. The site was about 1/4-mile northeast of the town of Round Rock. There were two burned rock middens separated stratigraphically. The lower midden dated from the Middle Archaic Period, and included Nolan, Pedernales, and Bulverde dart points. The upper midden dated from the Late Middle Archaic and the Early Late Archaic Periods. and included Pedernales and Bulverde dart points as well as Castroville and Frio dart points.

Other investigations in Williamson County include those by Sorrow (1969, 1970), Eddy (1973), and Shafer (1974). More recently, research in Williamson County has concentrated on the North Fork and Granger Reservoirs. Several sites in both reservoirs had components dating to the Round Rock Phase, but the only well-studied site in Central Texas with an isolated Round Rock Phase is the Loeve-Fox Site, 41WM230, (Prewitt 1982) in Granger Reservoir, in northeast Williamson County.

Other sites from the San Gabriel River with Round Rock Phase components include 41WM56, 41WM57, 41WM73, and 41WM304 from the North Fork Reservoir; and 41WM21, 41WM122, 41WM133, 41WM135, 41WM163, and 41WM267 in the Granger Reservoir(Moore 1977, 1978; Moore, Shafer, and Weed 1978; Hays 1982). Contrasts between these two reservoirs are interesting since the North Fork Reservoir is on the Balcones Escarpment while the Granger Reservoir is on the Blackland Prairie. On the Balcones Escarpment and Edwards Plateau, most of the Round Rock Phase sites are associated with burned rock middens. In the Blackland Prairie, Round Rock Phase sites tend not to be associated with burned rock middens.

The Wilson-Leonard site (41WM235) is several miles south of the North Fork Reservoir on Brushy Creek. It was a multicomponent site, but some portions of the site were well stratified. The Round Rock Phase at this site was expressed in the form of small hearth features (Young, personal communication). In addition, the Hoxie Bridge site, 41WM130 in Granger Reservoir, (Bond 1978) has features similar to those seen at 41WM13, but the components date from later time periods. 
The chronological sequences in the Central Texas Archaic are based primarily on projectile point typologies and associated radiocarbon dates. Currently two versions of the chronology are in use: Weir (1976) has suggested a sequence which is more generalized and contains five time periods. On the other hand Prewitt (1981) refined Weir's time periods by splitting them.into more categories. Johnson (1987) criticizes both schemes on methodological grounds, but does not offer an alternative. The definition of the Round Rock Phase represents the later half of the Middle Archaic Period in Weir's scheme and is the same as Prewitt's Round Rock and Marshall Ford Phases combined. The chronology presented below is based on that used for the North Fork and Granger Reservoir projects, and is a modified form of Weir's chronology:

$\begin{array}{lll}\frac{\text { Period }}{\text { Late Prehistoric }} & \frac{\text { Phase }}{\text { Toyah }} & \frac{\text { Dates (B.P.) }}{150-650} \\ & \text { Austin } & 650-1250 \\ \text { Archaic } & \text { Twin Sisters } & 1250-1750 \\ & \text { San Marcos } & 1750-2600 \\ & \text { Round Rock } & 2600-4000 \\ & \text { Clear Fork } & 4000-5000 \\ & \text { San Geronimo } & 5000-7000 \\ & \text { Circleville } & 7000-8000 \\ \text { Paleoindian } & & \\ & & 8000-\end{array}$

The Round Rock Phase is the major period of the Central Texas Middle Archaic, and the dominant component at 41WM13. Diagnostic artifacts for this time period include Pedernales and Bulverde dart points for the early portion of the phase, and Pedernales and Marshall dart points for the later portion of the phase. It is preceded by the Clear Fork Phase (Early/Middle Archaic) and superceded by the San Marcos Phase (Late Archaic). Round Rock Phase adaptations seem to derive out of the Clear Fork Phase and continue into later time periods.

The people of the Round Rock Phase are thought to have consisted of nomadic hunter/gatherer groups who exploited various resources seasonally. Burned rock middens occur in association with most Round Rock Phase sites and may represent periodic episodes where aggregations of hunting/gathering bands took part in communal food processing and cooking. Although burned rock middens in Central Texas have a variety of shapes (Weir 1976), Round Rock Phase is dominated by those with an oval shape.

The subsistence base seems to have stressed mussels, deer, and small game. Bison were not a large part of the subsistence, although bison remains are occasionally found. Floral resource exploitation is not well known, but acorns, pecans and walnuts were probably plentiful. 
Lithic resources are easily obtained. Along the Balcones Escarpment and on the Edwards Plateau there are many outcrops of chert, the local variety of which is called Georgetown chert. On the Blackland Prairie chert nodules are common in the creek gravels, where they have washed out of the Edwards Plateau. To the east and west of Williamson County many types of chert, jasper, and quartzite are available in Pleistocene gravel deposits called the Uvalde Gravels. Limestone is available throughout the area and the Cretaceous fossil oyster, Exogyra ponderosa, can be found in many of the limestone deposits of the region.

Pottery making was unknown. As with many non-ceramic cultures in North America, cooking methods probably relied on the use of "boiling stones" and roasting. Some types of food were probably placed directly among the heated rocks. The apparent emphasis on mussels and the frequency of small burned rock clusters in association with mussel shell probably attests to this type of cooking method as well.

The non-perishable material culture of the period was limited mainly to stone dart points and bifacial tools. Scraping tools are uncommon, and most are make-shift tools such as utilized flakes. Of the diagnostic implements, the Pedernales dart point is the most ubiquitous. It appears to have served as a multipurpose tool: used as a dart point, for cutting or drilling. These tools frequently show signs of wear, re-sharpening, and re-use.

There may be a distinction between the Round Rock Phase settlements on the Edwards Plateau and those of the Blackland Prairie. All the well-documented burned rock midden associations for the Round Rock Phase occur on the Balcones Escarpment and westward. Although burned rock middens may occur on the Blackland Prairie for other time periods, Round Rock Phase burned rock middens seem to be absent (Peter, Hays, and Demuynck 1982)

It is not known how many different ethnic or tribal groups are represented by Round Rock Phase sites, but Weir (1976) has suggested that there was a distinctive indigenous group in place in Central Texas by the MiddleArchaic Period. The region to the southeast of the study area has been considered to be a transitional zone between Coastal, Eastern, and Central Texas cultures since it shares traits with each of those culture areas. However, Goode (1984) hypothesized that the "transitional zone" was also a separate, distinct cultural area in the Middle Archaic period, centered on Fayette and Bastrop Counties, Texas.

There is no evidence at present to indicate any major disruption of the Central Texas Archaic Tradition. However, the social organization of the people of these time periods, the length of time involved, and the areal extent of the Central Texas region is such that it is likely that the Round Rock Phase identifies a collection of hunter-gatherer groups with similar, generalized adaptations. It would be reasonable to assume that intraregional divisions occur, but the chronology of the sites from the Round Rock Phase is not refined enough to make such identification possible at this time. 
Site 41 WM13 is on a terrace south of and immediately adjacent to Brushy Creek. Brushy Creek is a dependable source of water and is given to violent and sudden flooding, which has been brought under partial control only in recent years. Archaeological sites are numerous along the creek and its tributaries.

The site follows the south bank of the creek west and upstream from the Brushy Creek bridge for a distance of about 200 meters. Construction activities will be limited to a relatively small portion of the site, about 60 by 15 meters in size. Within the affected area, the site is level with little relief (as shown in Fig. 2). Native grasses, elm and pecan trees occur on the site.

Although the site as a whole may be multicomponent, the portion to be affected lies at the eastern extremity of the site and appears to represent several occupations by a single cultural entity, or at least contains a strongly dominant Middle Archaic component. 


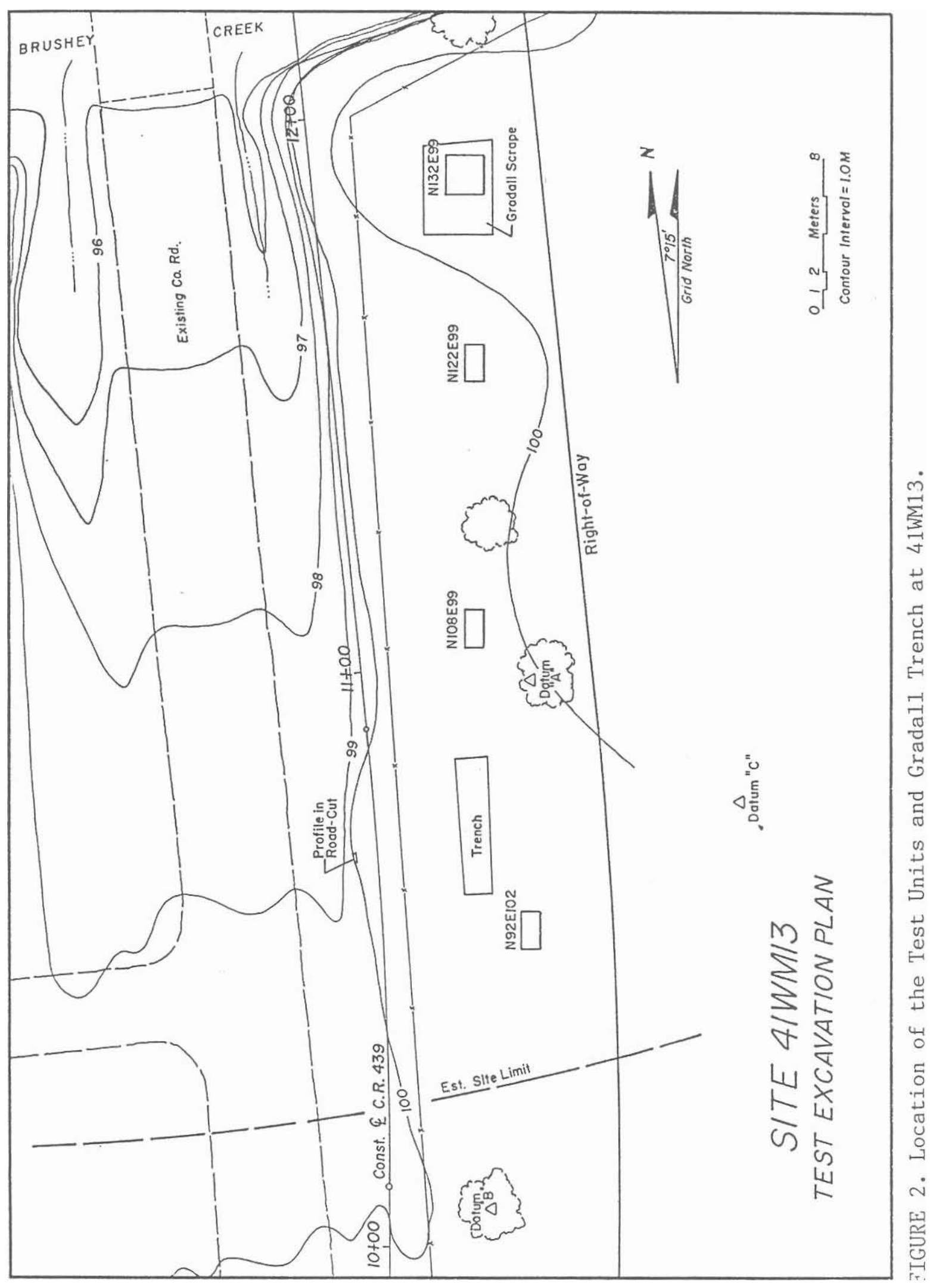




\title{
TEST EXCAVATIONS
}

\author{
Testing Procedures
}

Within the right-of-way, three 1 by 2 meter and one 2 by 2 meter test units were dug using, picks, shovels and trowels (Fig. 2). The units were excavated in arbitrary $10 \mathrm{~cm}$ levels to a sterile stratum consisting of a calcareous, yellowish gray, alluvial silt. All soil matrix from the test units was passed through screens of 1/4-in. hardware cloth. Artifacts recovered on the screens were placed in labelled bags. Level forms were completed for each level excavated. Artifacts found in situ were plotted on the level forms. Vertical control for the levels was measured from the surface using metric folding rules and tapes, while in situ artifacts were shot in with a transit.

After two of the 1 by 2 meter test units were excavated, it was decided that the upper $40 \mathrm{~cm}$ of deposit contained relatively little archaeological material. A Gradall was used to remove the upper $40 \mathrm{~cm}$ of $\mathrm{s}$ oil from a portion of the test area about 4 by 4 meters in size. The 2 by 2 meter test unit was placed within the scraped area and hand excavation began with level 5 (40 to $50 \mathrm{~cm}$ below the surface).

\section{Stratigraphy}

Stratigraphy at the impacted area of the site is uncomplicated (Fig. 3 and 4). The soil survey manual for Williamson County classifies the soil as Oakalla silty clay loam, which is a Cumulic Haplustoll (Werchan and Coker 1983). The A-horizon, as observed during testing, is a thick, dark gray clay loam extending from the surface to a depth of 80 or $90 \mathrm{~cm}$. This overlies an alluvial C-horizon made up of a light gray to yellowish silty loam. Weak paleosols and the cross-section of an ancient stream channel are visible in the creek bank upstream from the portion of the site which was tested.

In addition to the units which were excavated by hand, one trench was dug using a Gradall to a depth of 2.3 meters. The trench demonstrated that the silty alluvium visible at the bottom of the test units continued for at least one meter below the deepest hand excavated level. It also confirmed that weak paleosols which were visible about 100 meters upstream did not continue into the portion of the site being tested.

Immediately adjacent to the road, the light colored alluvium composing the Chorizon also occurs as overburden (Fig. 3, Zone I) above the A-horizon. The observed overburden is the result of construction waste accumulated during road construction and maintenance over the past 50 years. The overburden was not seen in any of the test units or the trench.

There seemed to be only limited disturbance of the subsoil. Rodent burrows were infrequent, and tree roots mainly affected the upper $50 \mathrm{~cm}$ of soil. The major source of disturbance were red ant nests, some of which were over a meter deep. 
ZONE 1 0-50 cm belor surface

Gray to 1t. gray Clay Iopm, subangular block,. A feu snail

fragment3, lots of tree roots.

ZONE I1 50-I20 C belou furface

Dark gray grading to gray with depth.

Clay loam. subangular blocky. A few

snail shells. few roota. This is $\theta$

buried A-horizon.

2ONE III 120-140 c⿴囗⿰丨丨 below surface Grey clay loam stmilar to bottom of Zone II. Lots of snail shell

end burned rock (limestone).

Also. flakes and mussel shell.

ZONE IV 140-180 cm below surface

Light gray silty alluvium. Fev

snails, no artifacts or wussel shell.

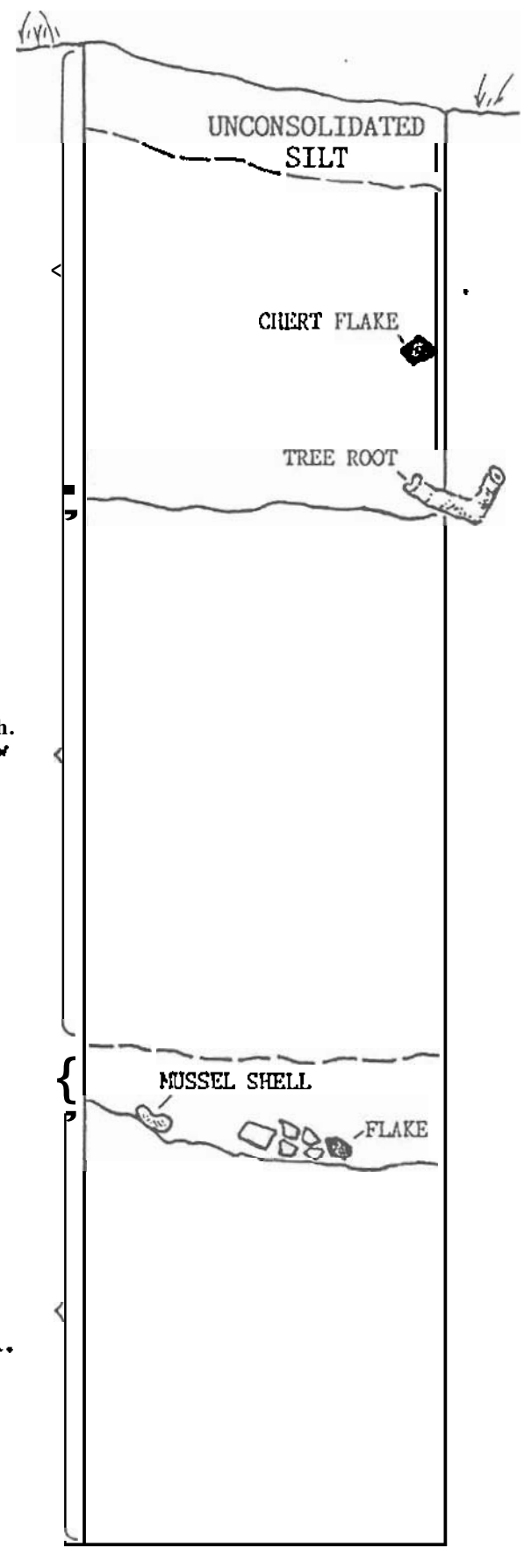

ROAD CUT PROFILE

EAST WALL

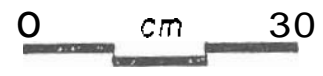

FIGURE 3. Profile of road cut, east side of CR 439 


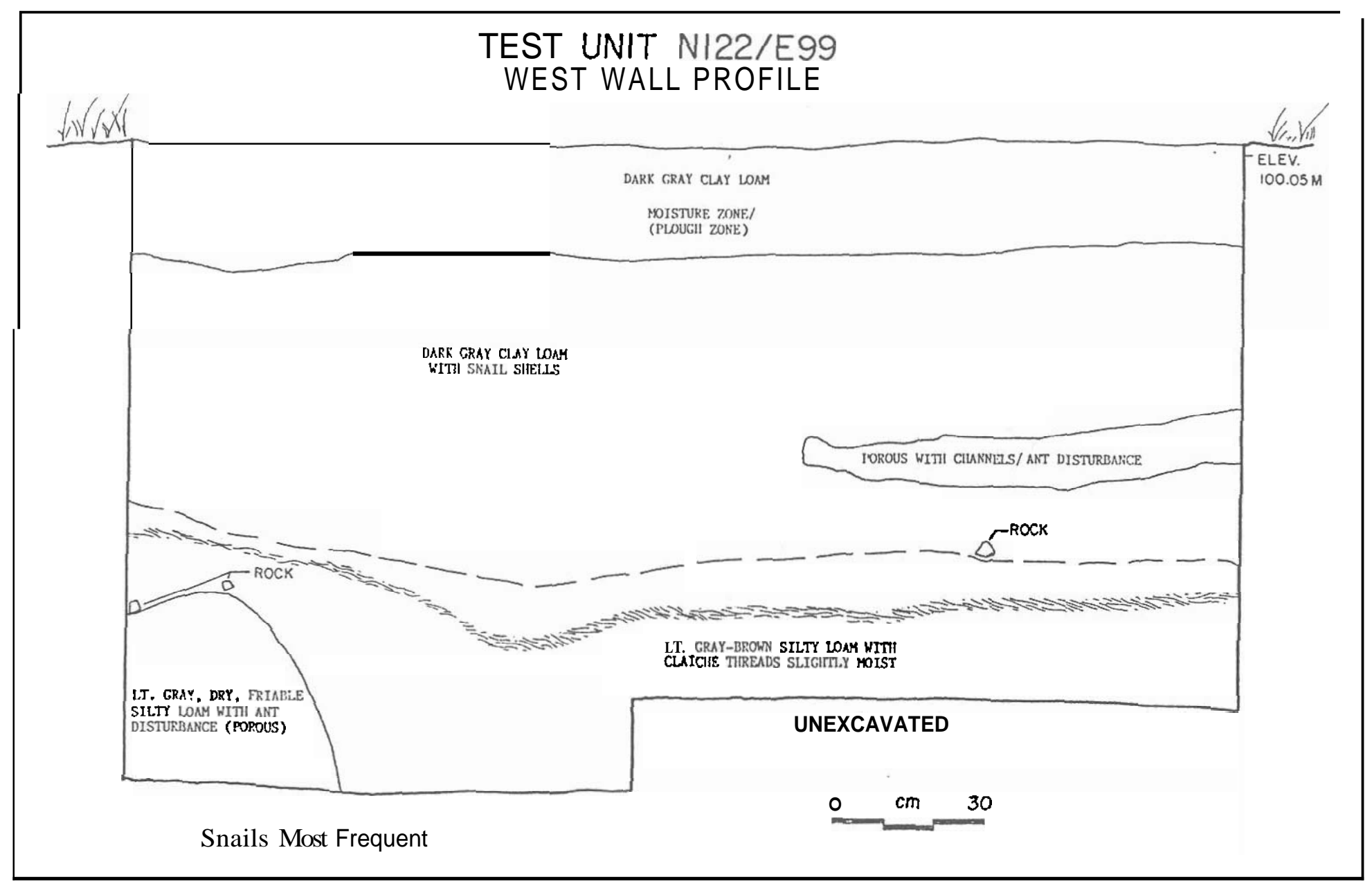




\section{Features}

Six features were identified in the four test units (Fig. 4, 5, and 6). They all occurred about 70 to $90 \mathrm{~cm}$ below the surface. All consisted of clusters of limestone and fossil Exogyra shell, with smaller amounts of chert, quartzite, and sandstone (Table 1). The rocks in these clusters appeared to be burned. The features all tended to be 10 to $25 \mathrm{~cm}$ thick and consisted of 2 or 3 courses of rock. All appeared to be constructed on flat surfaces were also flat on the upper surface, except Feature 4 which had a slight depression in the center. Mussel shell was common within these features. None of the mussel shell appeared to have been heavily burned and charcoal was not common, although it occasionally was found on the surfaces of some of the burned rocks.

The clusters occurred as two types: diffuse and compact. The diffuse clusters include Features 1, 2, and 5. Compact clusters include Features 3, 4, and possibly 6 . The diffuse clusters are interpreted as the remains of earlier hearths or refuse piles, while the compact clusters are interpreted as more recent hearths where rocks may have been borrowed from earlier hearths or refuse piles. The loose, unpatterned scatter of burned rock immediately below and adjacent to the compact clusters supports these interpretations.

Feature 3 (Fig. 6) exhibited an abundance of fossil Exogyra shell. The significance of the relatively high amount of fossil shell is unclear, but there is the possibility that Exogyra were preferred, at least for the activities pertaining to the feature. Exogyra were used in Feature 4 (Fig. 7), but was less frequent. It was even less frequent in the diffuse clusters.

Terrestrial snail shells, especially Rabdotus, were common in the soil of 41WM13. They were especially abundant at the bottom of the zones containing burned rock clusters. 


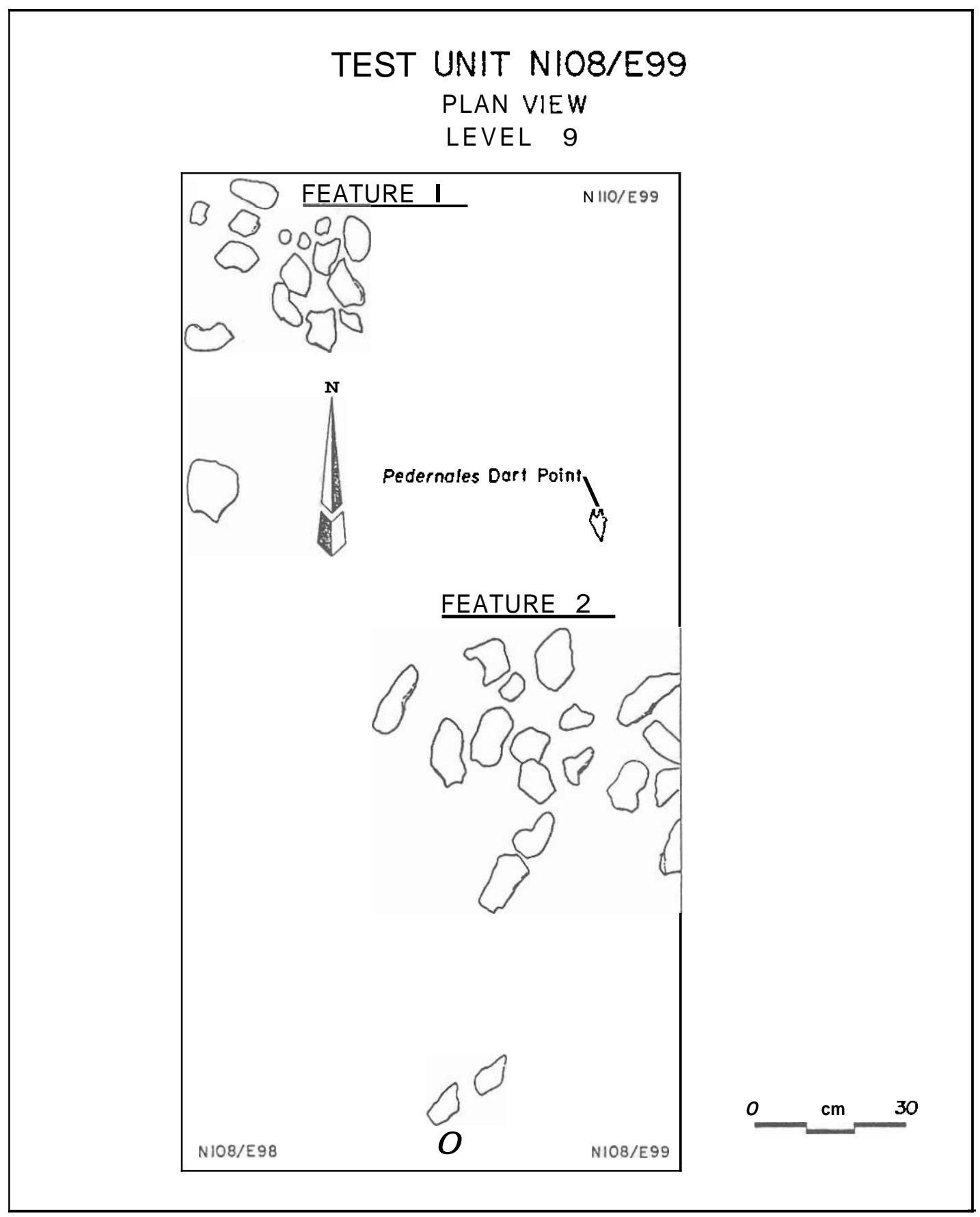

Figure 5. Test Unit N 108/E 99, L evel 9, F eatures 1 and 2. 


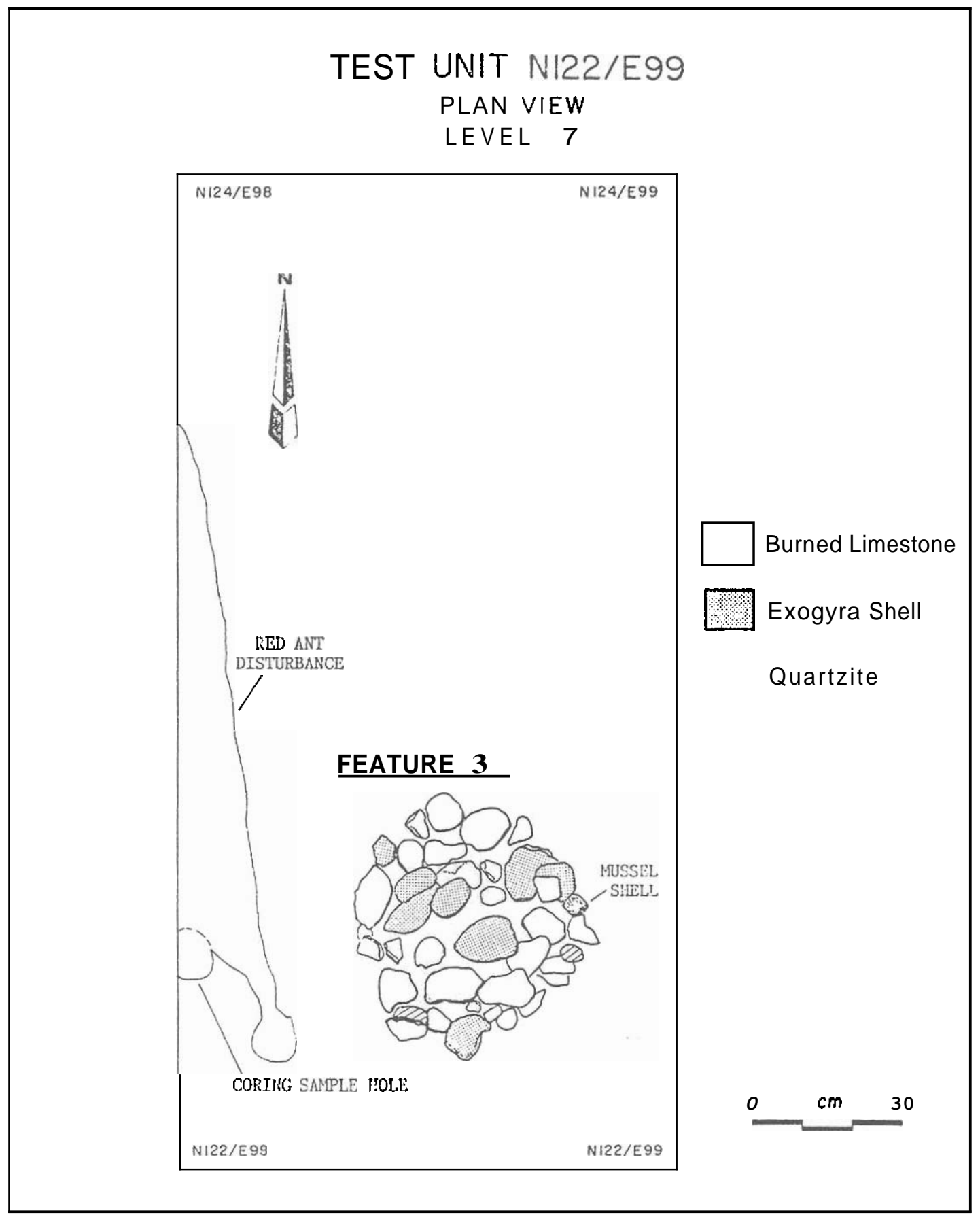

FIGURE 6. Test Unit N122/E99, Level 7, Feature 3. 


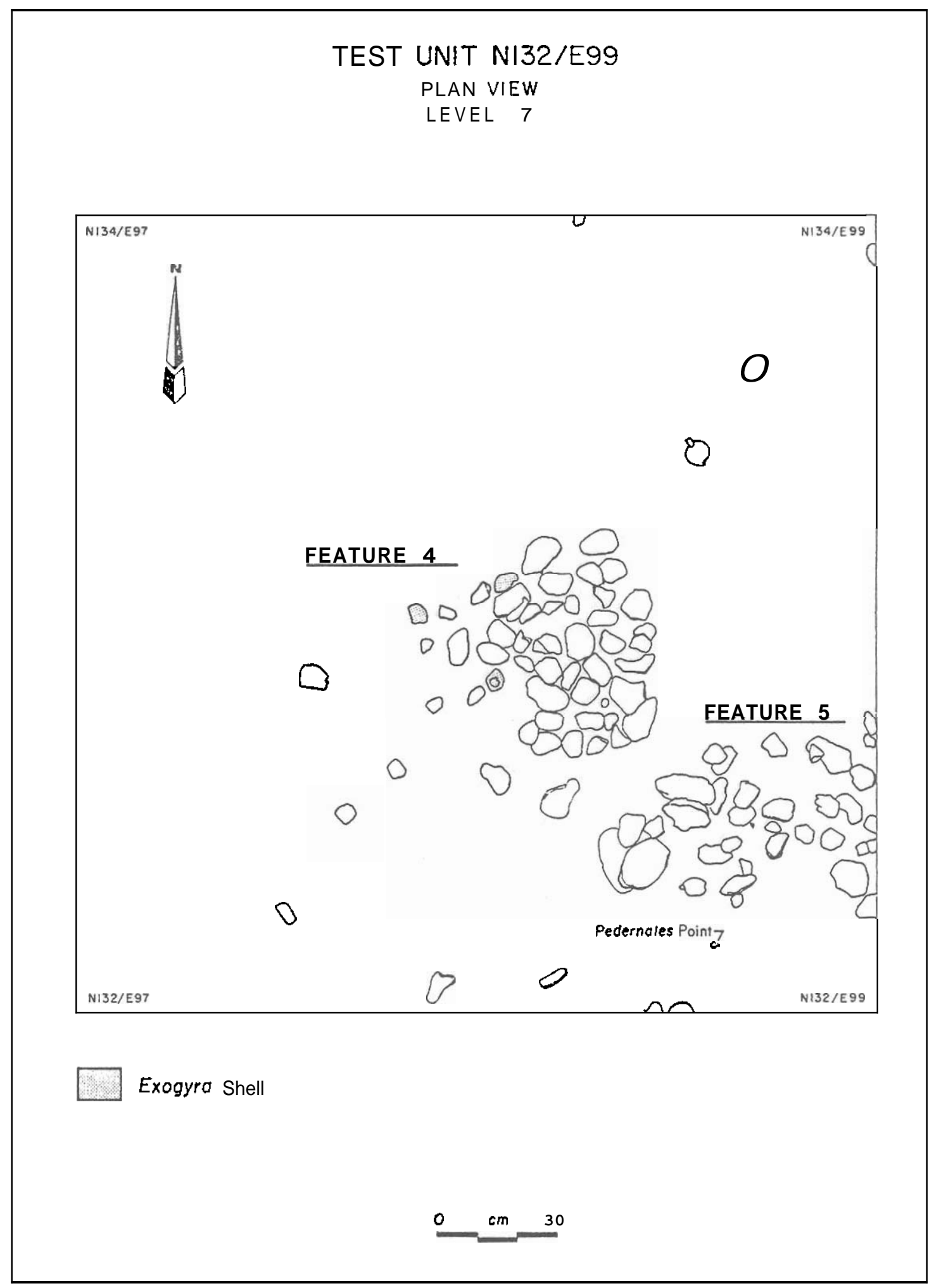

FIGURE 7. Test Unit N132/E99, Level 7, Features 4 and 5. 


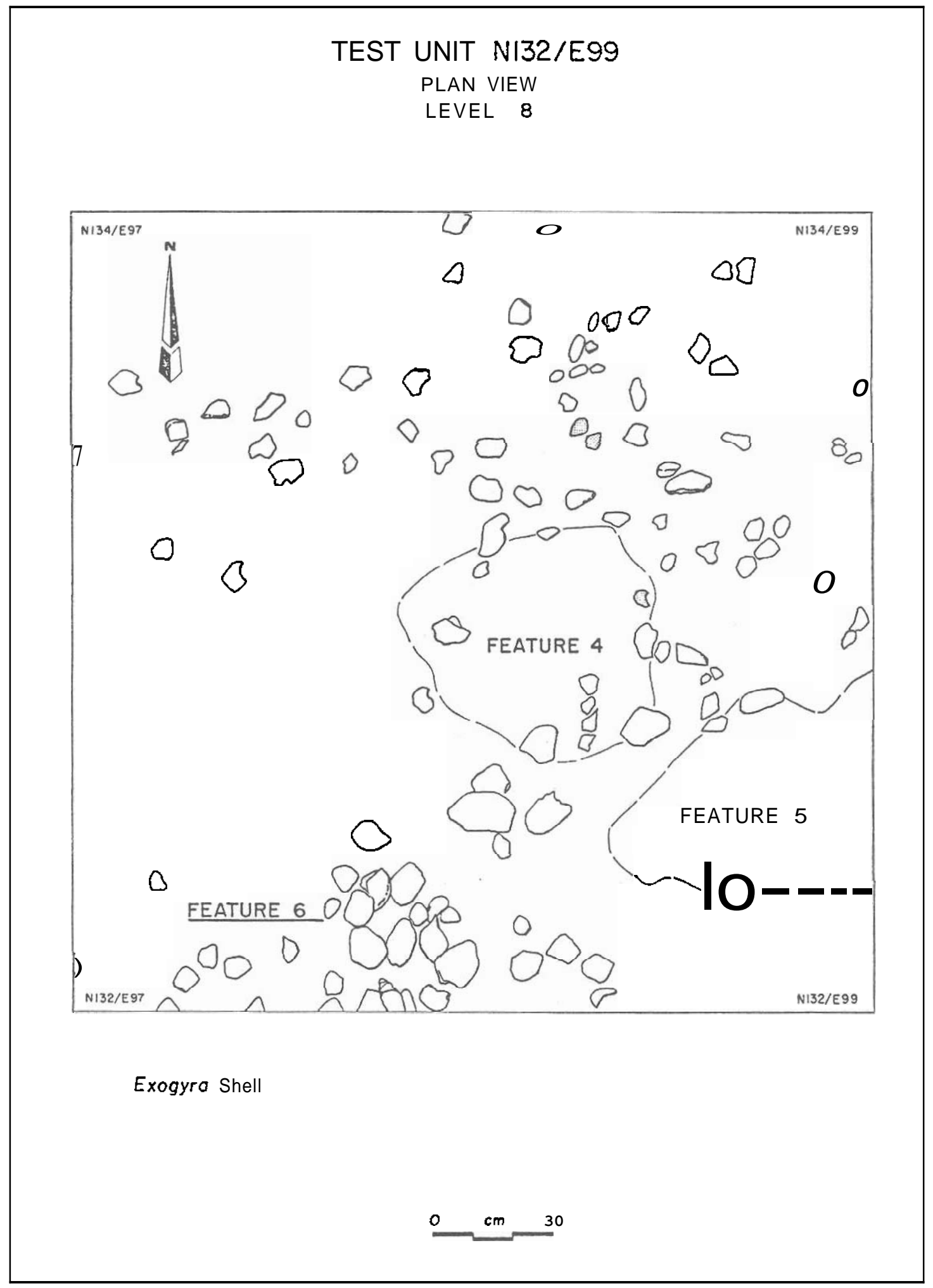

FIGURE 8. Test Unit N132/E99. Level 8, Features 4, 5, and 6. 
TABLE 1. Artifacts recovered from Features 1 through 6.

\begin{tabular}{|c|c|c|c|c|c|c|c|c|c|}
\hline \multirow[t]{2}{*}{ Provenience } & \multirow{2}{*}{$\begin{array}{l}\text { Volume } \\
\text { of Soil } \\
\text { Removed } \\
\left(\mathrm{m}^{3}\right)\end{array}$} & \multicolumn{5}{|c|}{ Chipped Stone (freq.) } & \multicolumn{3}{|c|}{ Burned Rock (gn) } \\
\hline & & Dart & $\begin{array}{l}\text { Other } \\
\text { Biface }\end{array}$ & $\begin{array}{l}\text { Mod. } \\
\text { Flake }\end{array}$ & Core & Flake & $\begin{array}{l}\text { Lime- } \\
\text { stone }\end{array}$ & Exogyra & Other \\
\hline Feature 1 & 0.014 & -- & -- & -- & -- & 2 & 2,111 & 43 & -- \\
\hline Feature 2 & 0.018 & -- & -- & -- & -- & -- & 2,584 & 201 & 45 \\
\hline Feature 3 & 0.016 & -- & -- & -- & -- & -- & 9,562 & 4,119 & 413 \\
\hline Feature 4 & 0.046 & -- & -- & -- & -- & 1 & 15.608 & 798 & 599 \\
\hline Feature 5 & 0.048 & -- & -- & 3 & 1 & 14 & 11,513 & 308 & 400 \\
\hline Feature 6 & 0.012 & -- & -- & -- & & 9 & 4,547 & 267 & 22 \\
\hline
\end{tabular}

TABLE 2. Faunal remains recovered from Features 1 through 6 .

\begin{tabular}{|c|c|c|c|c|}
\hline \multirow[t]{2}{*}{ Provenience } & \multirow{2}{*}{$\begin{array}{l}\text { Bone } \\
\text { Frag. } \\
\text { (gm) }\end{array}$} & \multirow{2}{*}{$\begin{array}{c}\text { Mussel } \\
\text { Shell } \\
\text { (gm) }\end{array}$} & \multicolumn{2}{|c|}{ Snail (gm) } \\
\hline & & & Rabdotus & Other \\
\hline Feature 1 & -- & -- & -- & -- \\
\hline Feature 2 & -- & -- & 1 & $1^{\prime}$ \\
\hline Feature 3 & -- & 11 & 15 & 3 \\
\hline Feature 4 & 1 & 6 & 80 & 2 \\
\hline Feature 5 & -- & 22 & 133 & 5 \\
\hline Feature 6 & -- & 21 & 15 & 1 \\
\hline
\end{tabular}




\section{Artifact Descriptions}

Quantities of artifacts and faunal remains associated with the six features are presented in Tables 1 and 2. Material recovered from the surface and in the remaining test excavations is listed in Tables 3 and 4 . The excavated levels appear to be comparable from test unit to test unit, which makes interpretation of vertical relationships relatively simple.

\section{Projectile Points}

A total of 8 dart points was found in the test units (Fig. 9, B-I) and are listed in Tables 3 and 4. Identifiable points include 1 Bulverde-like and 5 Pedernales dart points. The Bulverde-like specimen was found in Level 10, while the Pedernales points were found in Levels 7, 9 and 11. In addition, there were two unidentified dart point fragments; a rounded base found in Level 5, and an expanding stem found in Level 7. While none of the projectile points were found within any of the features, one of the Pedernales points (Fig. 9, B) was found adjacent to the upper portion of Feature 5.

\section{Other Bifaces}

A total of 12 bifaces and biface fragments was recovered. They tend to occur throughout the deposits, but the small sample prevents assessment of the relevance of their vertical distribution. All but one appear to have been abandoned in various stages of manufacture. Most have been thinned and well shaped. One of the bifaces (Fig. 9, A) is a knife which appears to be reworked along the base resulting in an asymmetric appearance.

\section{Modified/Utilized Flakes}

A total of 95 modified or utilized flakes was found. All but two of these flakes are made on small thinning flakes, most of which were created with a soft-hammer technique. The distal and lateral edges of these flakes were then used as make-shift tools for light duty as cutting and scraping implements. After being used a few times, they were then discarded,

Two of the modified flakes (Fig.11, A and B) are large flakes resulting from the early stages of lithic reduction. In this regard, they are atypical of all the other flakes found at 41WM13, including the unmodified flakes. One of the flakes has been used as a side scraper and one (Fig. 11, B) has evidence of pounding or chopping along one edge. This edge exhibits small hinge flakes and crushing, but is also rounded and smoothed. The implement may have been used to break up fibrous material, which would require pounding and cutting. 


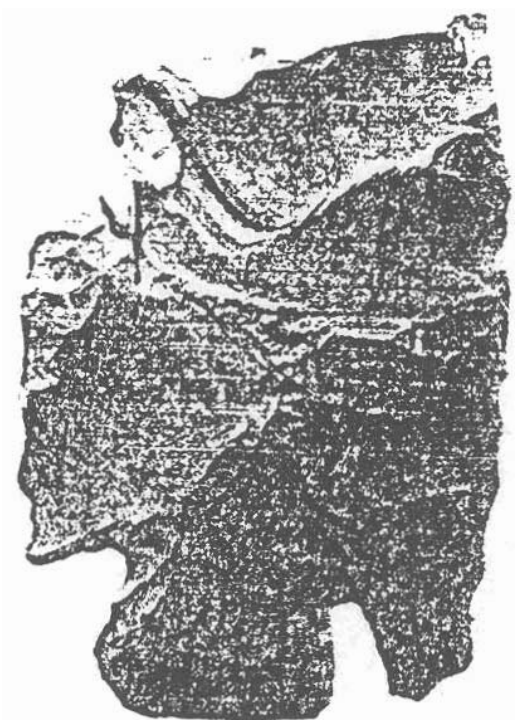

A

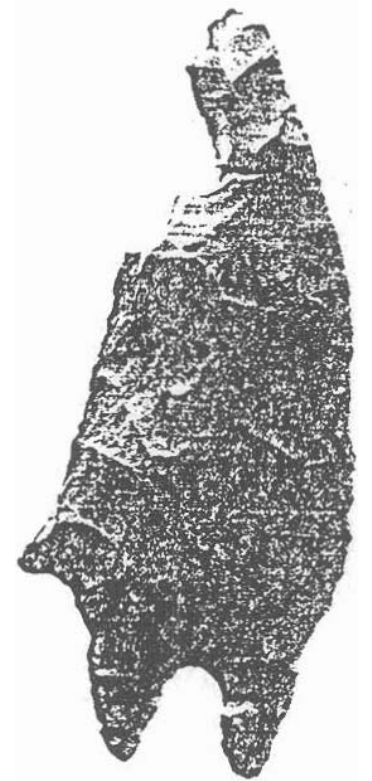

$\mathrm{E}$

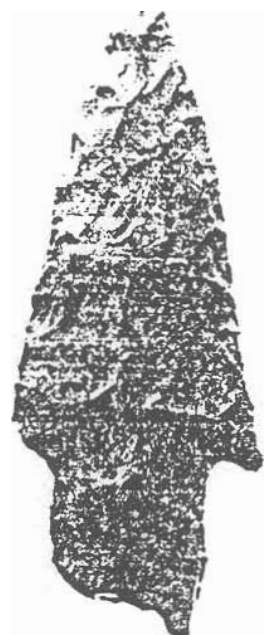

B

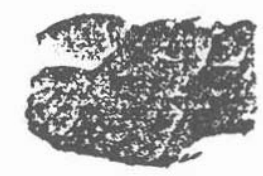

C

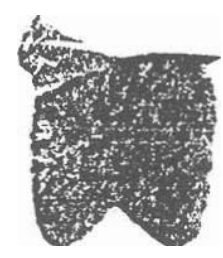

D

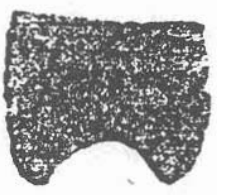

$\mathrm{F}$

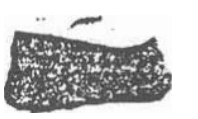

G

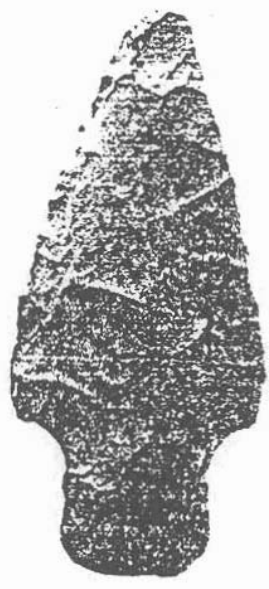

$\mathrm{H}$
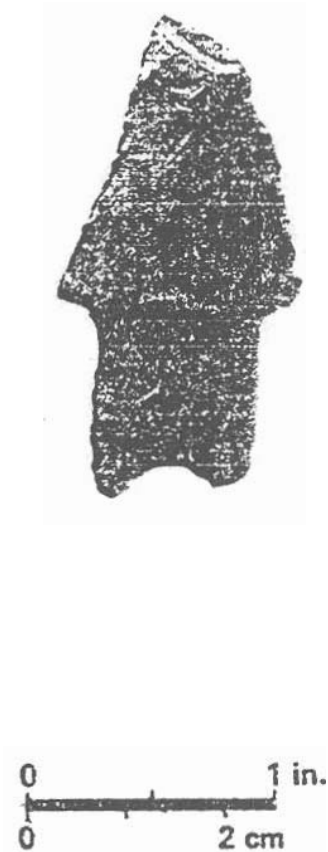

FIGURE 9. Knife and Dart Points from 41WM13. Kinfe (A), Pedernales point (B, D-F, I), Bulverde-like point (H), stem fragments (C, D). 


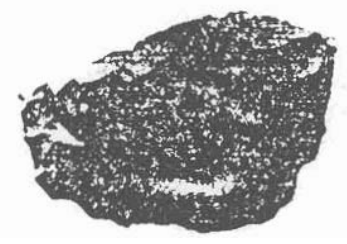

A

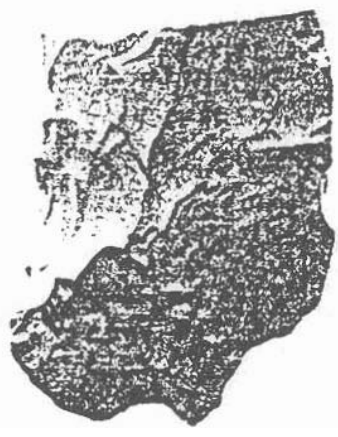

D

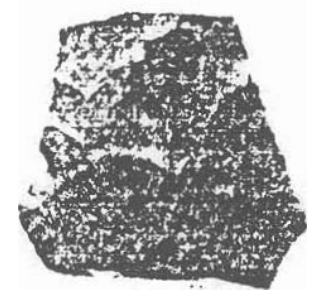

B

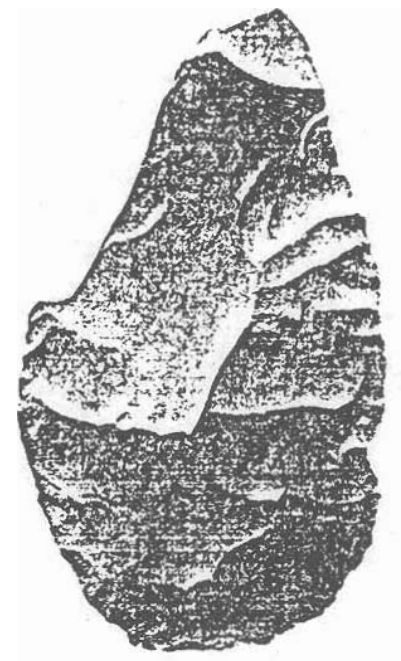

E

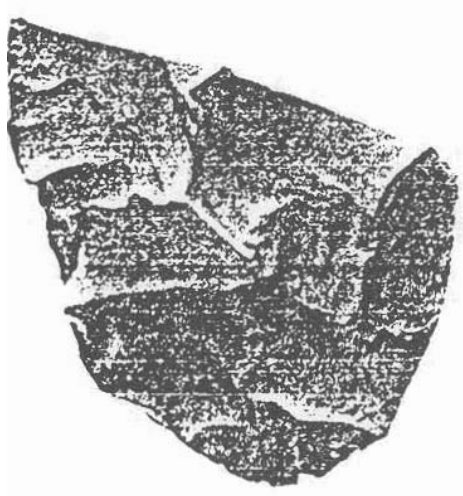

H

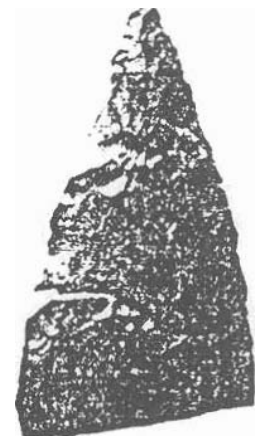

C

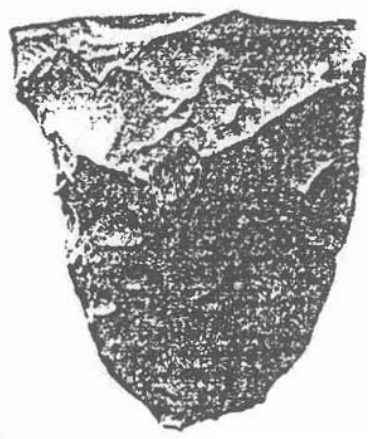

F
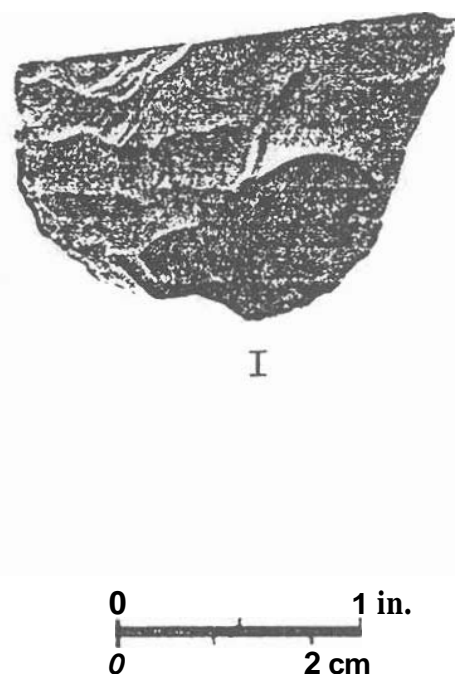

FIGURE 10. Bifaces from 41W M 13 

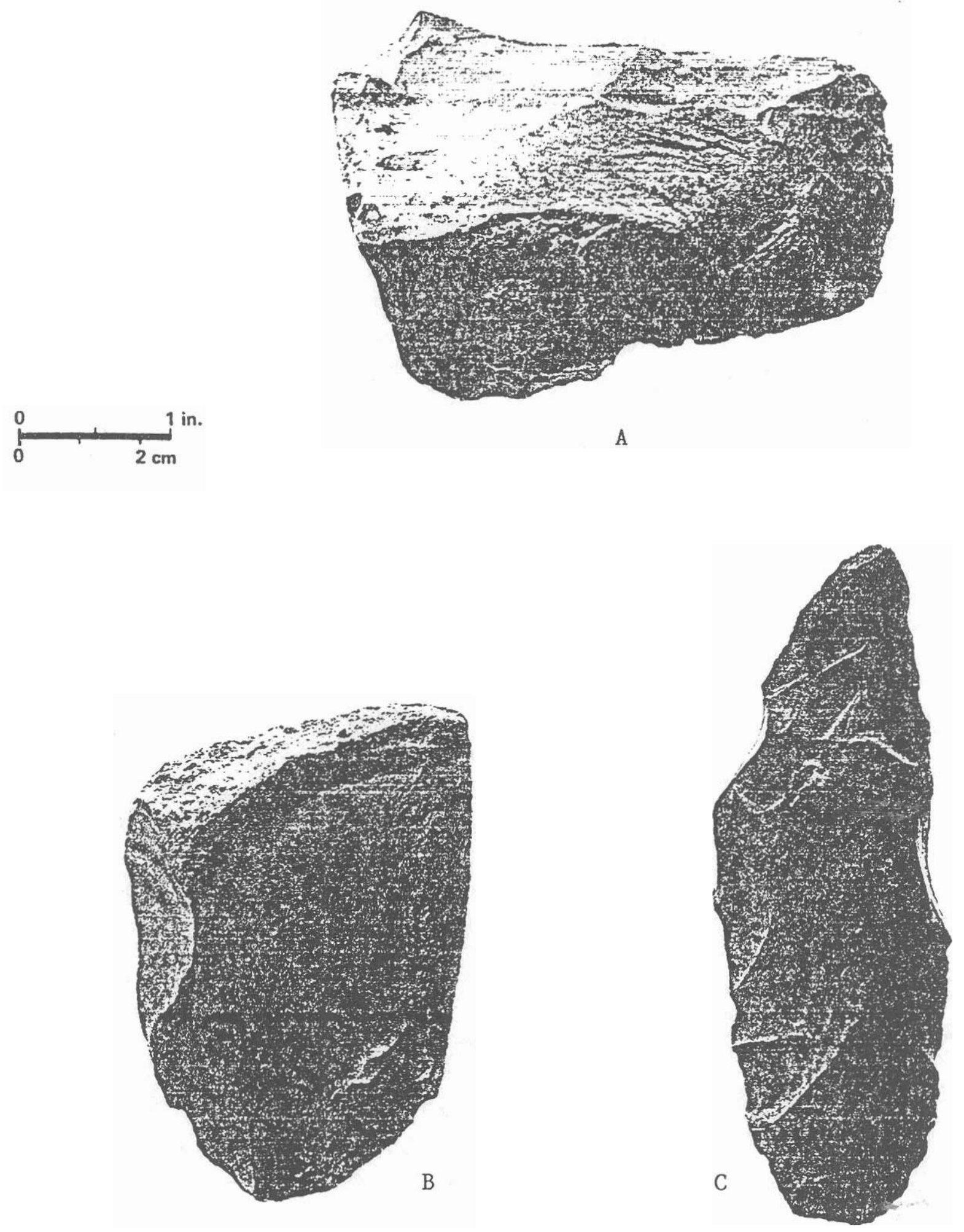

FIGURE 11. Assorted Artifacts from 41WM13. Side scraper/modified flake (A), scraper/chopper/modified flake (B), crude biface (C). 
TABLE 3. Artifact summary.

\begin{tabular}{|c|c|c|c|c|c|c|c|c|c|}
\hline \multirow[t]{2}{*}{ provenience } & \multirow{2}{*}{$\begin{array}{l}\text { Volume } \\
\text { of S o i } 1 \\
\text { Removed } \\
\left(\mathrm{m}^{3}\right)\end{array}$} & \multicolumn{5}{|c|}{ Chipped Stone (Ereq.) } & \multicolumn{3}{|c|}{ Burned Rock (gm) } \\
\hline & & Dart & $\mid \begin{array}{l}\text { Other } \\
\text { Biface }\end{array}$ & $\begin{array}{l}\text { Nod. } \\
\text { F1ake }\end{array}$ & Core & |Flake|| & $\begin{array}{l}\text { Lime- } \\
\text { stone }\end{array}$ & Exogyra & Other \\
\hline $\begin{aligned} & \text { N92 E102: } \\
& \text { Level } 1 \\
& \text { Level } 2 \\
& \text { Level } 3 \\
& \text { Level } 4 \\
& \text { Level } 5 \\
& \text { Level } 6 \\
& \text { Level } 7 \\
& \text { Level } 8 \\
& \text { Level } 9 \\
& \text { Level } 10\end{aligned}$ & $\begin{array}{l}0.200 \\
0.200 \\
0.200 \\
0.200 \\
0.200 \\
0.200 \\
0.200 \\
0.200 \\
0.200 \\
0.200\end{array}$ & $\begin{array}{l}-- \\
-- \\
-- \\
-- \\
-- \\
-- \\
-- \\
-- \\
-- \\
--\end{array}$ & $\begin{array}{l}-- \\
-- \\
-- \\
-- \\
-- \\
-- \\
1 \\
-- \\
-- \\
--\end{array}$ & $\begin{array}{r}-- \\
-- \\
-- \\
-- \\
3 \\
-- \\
1 \\
1 \\
-- \\
--\end{array}$ & $\begin{array}{l}-- \\
-- \\
-- \\
-- \\
1 \\
-- \\
-- \\
-- \\
-- \\
--\end{array}$ & $\begin{array}{r}2 \\
-- \\
-- \\
1 \\
14 \\
9 \\
8 \\
2 \\
2 \\
--\end{array}$ & $\begin{array}{r}438 \\
36 \\
-- \\
8 \\
24 \\
61 \\
43 \\
127 \\
2 \\
--\end{array}$ & $\begin{array}{r}12 \\
4 \\
1 \\
-- \\
6 \\
6 \\
2 \\
-- \\
-- \\
--\end{array}$ & $\begin{array}{r}-- \\
-- \\
1 \\
-- \\
2 \\
-- \\
-- \\
-- \\
-- \\
--\end{array}$ \\
\hline $\begin{array}{c}\text { N108 E99: } \\
\text { Level } 1 \\
\text { Level } 2 \\
\text { Level } 3 \\
\text { Level } 4 \\
\text { Level } 5 \\
\text { Level } 6 \\
\text { Level } 7 \\
\text { Level } 8 \\
\text { Level } 9 \\
\text { Level } 10 \\
\text { Level } 11 \\
\text { Level } 12\end{array}$ & $\begin{array}{l}0.200 \\
0.200 \\
0.200 \\
0.200 \\
0.200 \\
0.200 \\
0.200 \\
0.200 \\
0.168 \\
0.200 \\
0.200 \\
0.100\end{array}$ & $\begin{array}{l}-- \\
-- \\
-- \\
-- \\
-- \\
-- \\
-- \\
-- \\
1 \\
-- \\
1 \\
--\end{array}$ & $\begin{array}{r}-- \\
-- \\
1 \\
1 \\
-- \\
1 \\
-- \\
-- \\
-- \\
-- \\
-- \\
--\end{array}$ & $\begin{array}{r}3 \\
-- \\
3 \\
-- \\
2 \\
8 \\
5 \\
6 \\
3 \\
5 \\
-- \\
1\end{array}$ & $\begin{array}{l}-- \\
-- \\
-- \\
-- \\
-- \\
-- \\
1 \\
1 \\
-- \\
-- \\
--\end{array}$ & $\begin{array}{r}5 \\
12 \\
39 \\
19 \\
43 \\
45 \\
36 \\
62 \\
52 \\
12 \\
2 \\
1\end{array}$ & $\begin{array}{r}107 \\
-- \\
178 \\
38 \\
75 \\
101 \\
216 \\
2,322 \\
1,031 \\
228 \\
62 \\
--\end{array}$ & $\begin{array}{r}9 \\
6 \\
10 \\
4 \\
13 \\
15 \\
10 \\
302 \\
88 \\
16 \\
10 \\
1\end{array}$ & $\begin{array}{r}24 \\
1 \\
79 \\
-- \\
13 \\
43 \\
25 \\
150 \\
166 \\
78 \\
12 \\
--\end{array}$ \\
\hline $\begin{array}{c}\text { 122 E99: } \\
\text { Level } 1 \\
\text { Level } 2 \\
\text { Level } 3 \\
\text { Level } 4 \\
\text { Level } 5 \\
\text { Level } 6 \\
\text { Level } 7 \\
\text { Level } 8 \\
\text { Level } 9 \\
\text { Level } 10 \\
\text { Level } 11 \\
\text { Level } 12 \\
\text { Level } 13\end{array}$ & $\begin{array}{l}0.200 \\
0.200 \\
0.200 \\
0.200 \\
0.200 \\
0.192 \\
0.184 \\
0.200 \\
0.200 \\
0.200 \\
0.200 \\
0.100 \\
0.100\end{array}$ & $\begin{array}{r}-- \\
-- \\
-- \\
-- \\
-- \\
-- \\
1 \\
-- \\
-- \\
1 \\
-- \\
-- \\
--\end{array}$ & $\begin{array}{l}-- \\
-- \\
-- \\
-- \\
1 \\
-- \\
-- \\
1 \\
1 \\
-- \\
-- \\
-- \\
--\end{array}$ & $\begin{array}{r}1 \\
-- \\
-- \\
-- \\
1 \\
-- \\
6 \\
1 \\
4 \\
1 \\
3 \\
1 \\
--\end{array}$ & $\begin{array}{l}-- \\
-- \\
-- \\
-- \\
-- \\
-- \\
1 \\
-- \\
-- \\
-- \\
-- \\
-- \\
--\end{array}$ & $\begin{array}{r}11 \\
3 \\
14 \\
10 \\
7 \\
32 \\
43 \\
8 \\
12 \\
33 \\
7 \\
3\end{array}$ & $\begin{array}{r}153 \\
6 \\
13 \\
169 \\
159 \\
107 \\
2,021 \\
5,099 \\
5,166 \\
2,085 \\
63 \\
41 \\
15\end{array}$ & $\begin{array}{r}18 \\
4 \\
14 \\
12 \\
6 \\
18 \\
294 \\
26 \\
106 \\
37 \\
11 \\
-- \\
--\end{array}$ & $\begin{array}{r}-- \\
3 \\
-- \\
-- \\
147 \\
74 \\
190 \\
362 \\
-- \\
30 \\
-- \\
-- \\
15\end{array}$ \\
\hline
\end{tabular}


TABLE 3. Artifact summary (continued).

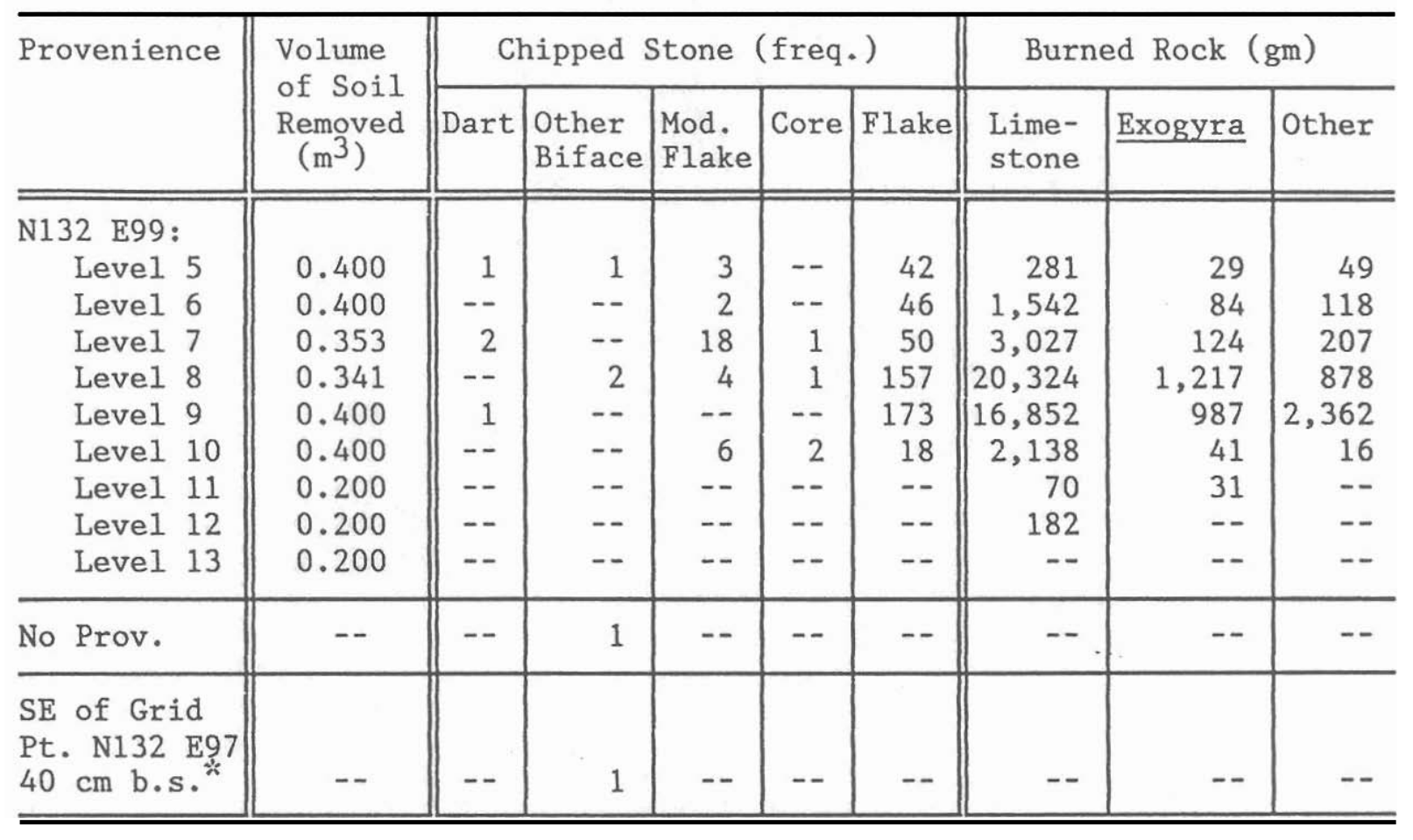

*Note: "b.s." = "below surface" 
Table 4. Faunal remains.

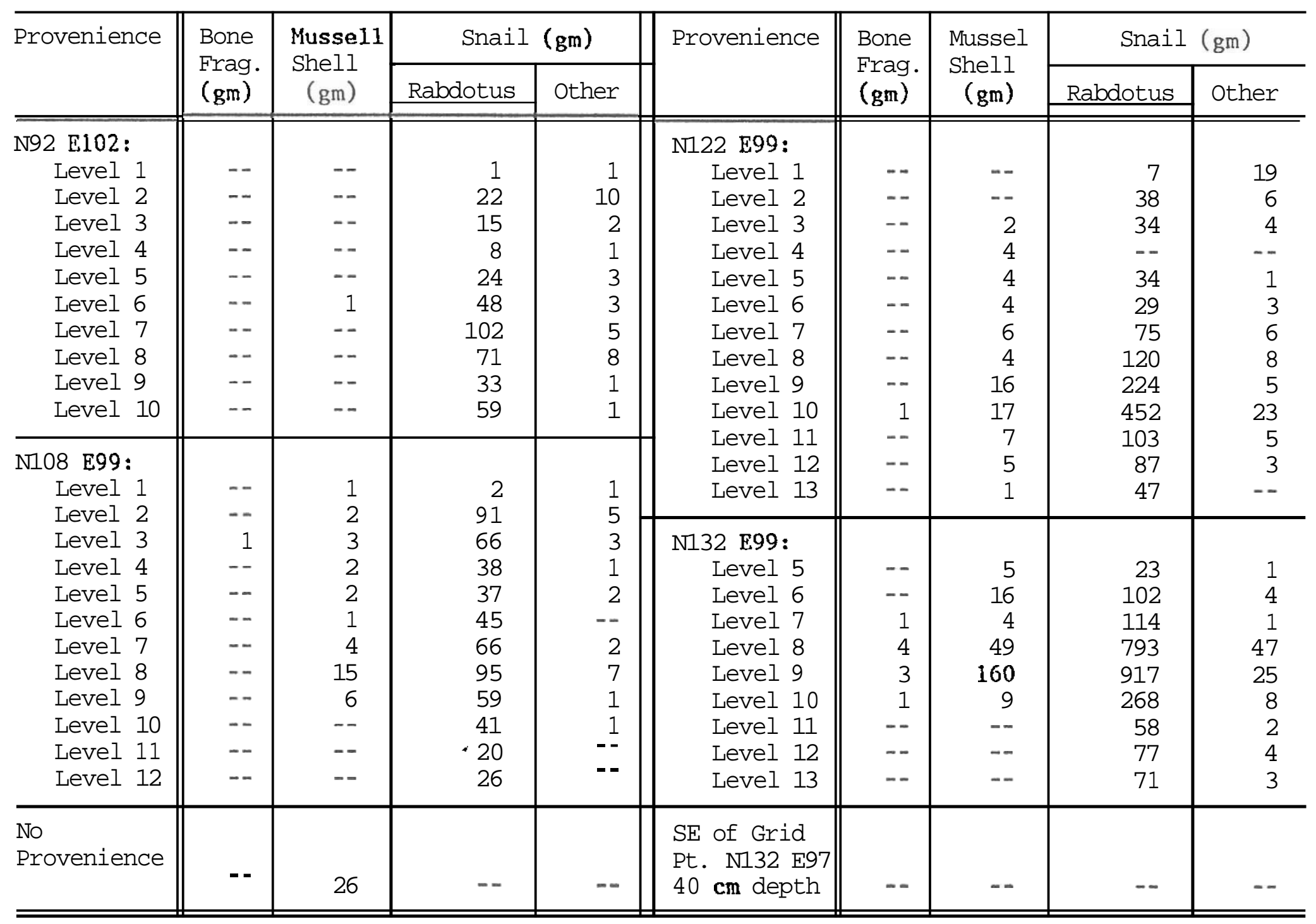




\section{Cores}

A total of 9 cores was recovered. Flaking was from many directions and irregular. Platform preparation is frequently present in the form of light chipping or grinding. Generally, the cores had not been exhausted or efficiently flaked. All the cores are of locally available chert Edwards Plateau chert.

\section{Unmodified Flakes}

A total of 1035 unmodified flakes was found. Of these, 3\% were primary, 24\% were secondary, and 56\% were interior flakes. The remaining $17 \%$ were shatter consisting of chips whose origins could not be determined. Almost all of the flakes were small and thin and were the result of soft-hammer percussion or pressure flaking.

\section{Burned Rock}

Burned rock has been discussed with reference to the features. The majority of burned rock was of limestone, but fossil Exogyra shell was also common. Minor amounts of burned chert, quartzite, sandstone, and a light weight conglomerate were also found. The rock probably came from the gravels found in Brushy Creek immediately adjacent to the site.

\section{Mussel Shell}

Fragments of mussel shell were found scattered throughout the test excavations, and are summarized in Tables 2 and 4. Most of the shell was found within the features, or in the same levels. Vertical distributions of the mussel shell follow those for flakes and burned rock fairly closely. None of the shell appears to have been heavily burned, although it is presumed that the mussels were being cooked and eaten because of their association with the burned rock.

$\underline{\text { Bone }}$

Very little bone was recovered. In part, the lack of bone is probably the result of poor preservation. The only bone recovered consisted of fragments too small to identify, although a few fragments appear to be from small mammals.

\section{Terrestrial Snail Shell}

Most of the snail shell recovered consisted of Rabdotus; a ubiquitous species throughout Texas. Other species of snail were recovered in small amounts. Adult Rabdotus were just large enough to not fall through a 1/4-inch mesh. other types of terrestrial snail are smaller and this accounts for the 
differential recovery rates for Rabdotus versus other species. The snails occurred in high frequencies at the same depth as the burned rock features, and just below. The accumulations of snail at these depths probably indicates a relatively slow deposition during part of Round Rock Phase or that relatively high amounts of organic material once attracted snails to the burned rock features and the areas surrounding them. 
In summary, 41WM13 appears to be a prehistoric camp site with an isolated, or strongly dominant Round Rock Phase component. Features present at the site include numerous small hearths of burned rock. No pits were observed, but may be present elsewhere. No burned rock midden was found, and the site may lack this type of feature.

Although the site covers an area of about 4 acres, only a portion 60 by 15 meters will be affected by the bridge replacement project. However, test excavations at the site revealed that 41WM13 has intact deposits with a high density of features from a limited number of components. The site meets the criteria for eligibility for the National Register of Historic Places (CFR 36, Part 800). Further excavation is recommended. 


\section{REFERENCES CITED}

Blair, Frank W.

1950 The Biotic Provinces of Texas. Texas Journal of Science 2(1).

Bond, Clell L.

1978 Three Archeological Sites at Hoxie Bridge, Williamson County, Texas. Report No. 43. Anthropology Laboratory, Texas A \& M University, College Station.

Campbell, Tom N.

1948 The Merrell Site: Archaeological Remains Associated with Alluvial Terrace Deposits in Central Texas. Texas Archeological and Paleontological Society 19:7-35.

Goode, Glenn T.

1984 Archaeological Testing and Recommendations for the Kennedy Bluffs Site, 41BP19, in Bastrop County, Texas. Texas State Department of Highways and Public Transportation, Austin.

Gould, F.W.

1969 Texas Plants: A Checklist and Ecological Summary. Texas Agricultural Experiment Station, Texas A \& M University, College Station.

Hays, T.R. (editor)

1982 Archaeological Investigations at the San Gabriel Reservoir Districts, Central Texas, Volumes I, I I, and III. Institute of Applied Sciences, North Texas State University, Denton.

Johnson, LeRoy

1987 A Plague of Phases: Recent Sociocultural Taxonomy in Texas

Archeology. Texas Archeological Society, Bulletin 57:1-26.

Moore. Gary L.

1977 An Archaeological Assessment of Sites 41WM21, 41WM24, and 41WM133 in Granger Reservoir, Williamson County, Texas. Report submitted to the National Park Service by the Anthropology Laboratory, Texas A \& M University, College Station.

Moore, Gary L., Harry J. Shafer, and C.S. Weed

1978 Archeological Surveys of the Granger and North Fork Reservoirs: Volume I, The Granger Report. Anthropology Laboratory, Texas A \& M University, College Station.

Peter, Duane E., T.R. Hays, and Marie-Anne Demuynck

1982 Synthesis: The Archaeology of the San Gabriel Reservoir Districts. In Archaeological Investigations at the San Gabriel Reservoir Districts, Central Texas, Volume 2, T.R. Hays, editor. North Texas State University, Denton. 
Prewitt, Elton R.

1981 Cultural Chronology in Central Texas. Texas Archeological Society, Bulletin 52: 65-90.

1982 Archaeological Investigations at the San Gabriel Reservoir Districts, Central Texas, Volume 4. Institute of Applied Sciences, North Texas State University, Denton.

Weir, Frank A.

1976 The Central Texas Archaic. Ph.D. dissertation, Washington State University, Pullman, Washington.

Werchan, Leroy E., and John L. Coker

1983 Soil Survey of Williamson County, Texas. United States Department of Agriculture, Soil Conservation Service, Washington, D.C.

Young, Wayne C.

1988 Personal communication with Alan J. Wormser, December 1988, at the offices of the Texas State Department of Highways and Public Transportation, Austin, Texas. 